Elżbieta Zakrzewska-Manterys

Uniwersytet Warszawski

\title{
Praca. Co to znaczy? Doświadczenia osób upośledzonych umysłowo związane \\ z zatrudnieniem
}

DOI: http://dx.doi.org/10.18778/1733-8069.14.3.08

Abstrakt W artykule omówione zostało znaczenie, jakie ma praca zarobkowa dla dorosłych osób niepełnosprawnych intelektualnie w stopniu umiarkowanym bądź znacznym. Na postawie wywiadów pogłębionych dokonano analizy 19 studiów przypadków opisujących doświadczenia związane z zatrudnieniem niepełnosprawnych intelektualnie mieszkańców Warszawy.

Słowa kluczowe niepełnosprawność intelektualna, upośledzenie umysłowe, praca, dorosłość, tożsamość

Elżbieta Zakrzewska-Manterys jest profesorem socjologii. Pracuje w Instytucie Stosowanych Nauk Społecznych Uniwersytetu Warszawskiego. Zajmuje się metodologią nauk społecznych oraz problematyką wykluczenia społecznego, zwłaszcza z powodu niepełnosprawności. Jest autorką kilku monografii oraz kilkudziesięciu artykułów naukowych i popularnonaukowych na ten temat.

\section{Adres kontaktowy:}

Instytut Stosowanych Nauk Społecznych

Uniwersytet Warszawski

Nowy Świat 69

00-927 Warszawa

e-mail: ezakrzewska@isns.uw.edu.pl ka osób niepełnosprawnych intelektualnie mieszka razem przez kilka tygodni, aby przekonać się, czy w przyszłości będą $\mathrm{w}$ stanie samodzielnie zamieszkać w systemie mieszkalnictwa chronionego (Zakrzewska-Manterys 2017: 197-232).

Innym ważnym obszarem jest sfera zatrudnienia. „Ustawa o rehabilitacji i zatrudnieniu (podobnie jak jej kolejne wcielenia) stawia sobie za cel wyrównanie powstałych $\mathrm{w}$ wyniku niepełnosprawności różnic $\mathrm{w}$ szansach na rynku pacy. Ciągle jednak zatrudnienie osób niepełnosprawnych pozostaje na niewysokim poziomie, a ich dochody uzyskiwane z pracy, nawet jeżeli wsparte świadczeniami rentowymi czy opiekuńczymi, plasują te osoby najczęściej na marginalizowanych pozycjach" (Ostrowska 2015: 106-107).

Z punktu widzenia polskiego ustawodawstwa, „sytuacja osób niepełnosprawnych na rynku pracy jest rozwiązana i gwarantuje im pełnię praw, podobnie jak osobom pełnosprawnym" (Kukla, Duda, Czerw-Bajer 2011:109). Jeśli więc chodzi o zapisy prawne, "teoretycznie" osoby niepełnosprawne mają równy z wszystkimi innymi obywatelami dostęp do zatrudnienia i pełnego uczestnictwa w rynku pracy. Mimo to jednak wiele osób niepełnosprawnych albo nigdy nie pracowało, albo też zatrudnienie ich było bardzo nietrwałe. Jak podaje Biuro Pełnomocnika Rządu do Spraw Osób Niepełnosprawnych, w 2016 roku współczynnik aktywności zawodowej osób niepełnosprawnych w wieku produkcyjnym wyniósł $26,8 \%$, wskaźnik zatrudnienia - 23,7\%1. W tym samym roku wskaź-

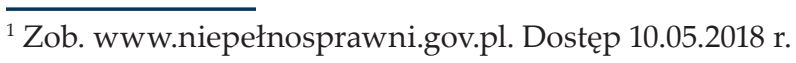

niki te dla populacji ogólnej wynosiły odpowiednio $56,3 \%$ oraz $52,7 \%{ }^{2}$ Dysproporcje te wskazują na ogromną skalę zjawiska.

Osoby niepełnosprawne intelektualnie stanowią wśród ogółu niepełnosprawnych zbiorowość specyficzną, a specyfika ta najwyraźniej daje o sobie znać $\mathrm{w}$ obszarach związanych $\mathrm{z}$ pełnieniem ról społecznych dorosłego człowieka, w tym zwłaszcza w obszarze zatrudnienia. „Najniższe wskaźniki aktywności zawodowej osób niepełnosprawnych związane są z upośledzeniem umysłowym oraz ze schorzeniami narządu słuchu - odpowiednio 8,5\% i 11,9\%" (Kukla i in. 2011: 109). Autorzy przywoływanego opracowania analizują możliwości zatrudnienia wybranych grup osób niepełnosprawnych. Grupa osób upośledzonych umysłowo omawiana jest łącznie z grupą chorych psychicznie. Autorzy piszą: „osoby upośledzone umysłowo stanowią grupę bezrobotnych, która ma największe trudności w uzyskaniu zatrudnienia. Sytuacja ta spowodowana jest istnieniem barier społecznych oraz stereotypów dotyczących przekonania społeczeństwa o braku wartości pracy osób upośledzonych umysłowo i psychicznie chorych" (Kukla i in. 2011: 127). Mimo więc deklaratywnego zrównywania szans osób upośledzonych umysłowo na rynku pracy, ich sytuacja pozostawia wciąż wiele do życzenia.

Trudności związane ze śledzeniem zmian, jakie zachodzą w zatrudnieniu osób niepełnosprawnych intelektualnie, polegają na tym, że badań takich jest bardzomało.Większośćautorów podejmujących problematykę zatrudniania osób niepełnosprawnych podejmowane są coraz częściej próby organizowania "turnusów” w mieszkaniach treningowych. Kil- 
pomija grupę osób niepełnosprawnych intelektualnie. Przykładowo, w szeroko zakrojonych ogólnopolskich badaniach wykonanych w 2007 roku w ramach projektu SWPS pod kierownictwem profesor A. Brzezińskiej wyróżniono następujące niepełnosprawności: słuchu, wzroku, psychiczną, somatyczną (Giermanowska 2016: 77). W książce Polscy niepetnosprawni, mimo że, jak twierdzi recenzent, „przedstawia całościową diagnozę sytuacji społecznej osób niepełnosprawnych w Polsce", osoby niepełnosprawne intelektualnie nie są ujęte w kontekście zatrudnienia (Gąciarz, Rudnicki 2014). Pisząc o projektach wspóffinansowanych przez Unię Europejską, udzielających wsparcia na rynku pracy, których beneficjentami były młode osoby niepełnosprawne, Monika Struck-Peregończyk (2017: 128-129) twierdzi, że "do końca 2013 r. udział w nich zakończyło ok. 10,6 tys. osób niepełnosprawnych", wsparcia udzielano osobom głuchoniewidomym, niepełnosprawnym ruchowo, niesłyszącym, niewidomym, osobom z autyzmem. Projektów skierowanych ku osobom niepełnosprawnym intelektualnie autorka nie wymienia. Tak więc brak jest systematycznej wiedzy na temat udziału osób upośledzonych umysłowo w rynku pracy. Niniejsza analiza jest jedną z nielicznych prób przybliżenia znaczenia pracy dla procesów tożsamościowych upośledzonych umysłowo pracowników. Działania podejmowane przez organizacje pozarządowe działające na rzecz osób niepełnosprawnych intelektualnie mają charakter niszowy i obejmują wsparciem doradztwa zawodowego bardzo niewielką liczbę osób. Przykładowo, Centrum DZWONI (Doradztwa Zawodowego i Wspierania Osób z Niepełnosprawnością Intelektualną) za ogromny swój sukces uznaje wsparcie udzielane od 1 kwietnia 2017 roku do 31 marca 2018 roku kilkudziesięciu osobom: „Ze wsparcia oferowanego przez Centra DZWONI skorzystało 155 osób z niepełnosprawnościami. 41 osób z tej grupy korzystało ze wsparcia w utrzymaniu zatrudnienia, natomiast aż 55 osób podjęło pierwsze w życiu zatrudnienie. 56 osób z tej grupy na koniec pierwszego okresu realizacji osiągnęło II wskaźnik rezultatu - czyli przez 6 miesięcy utrzymali zatrudnienie $\mathrm{w}$ trybie ciągymm"3. Wsparcie zatrudnieniowe ma więc charakter projektowy, odznacza się bardzo dużą intensywnością wynikającą z projektowego finansowania oraz - wiążącą się właśnie z charakterem projektowym - nietrwałością. 6-miesięczny okres zatrudnienia to $\mathrm{w}$ projekcie „osiągnięcie rezultatu", natomiast w karierze biograficznej upośledzonej osoby może to być nic nieznaczący, a nawet destrukcyjny, incydent. Zanalizowane poniżej studia przypadków ukierunkowane są na skonfrontowanie bardzo optymistycznego opisu działań ukierunkowanych na wsparcie „beneficjentów projektu” z "prozą życia” kariery zatrudnieniowej zwykłych uczestników życia społecznego.

Podejmowanie pracy przez osoby niepełnosprawne intelektualnie może być różnie rozumiane. Nie zawsze jest to płatna praca najemna. Zdarza się, że osoby takie pracują w firmie rodzinnej, w rodzinnym gospodarstwie rolnym, zajmują się domem, opiekują dziećmi czy wykonują inne formy pracy nieodpłatnej. Brak jest systematycznych badań w kompleksowy sposób ujmujących te zróżnicowane możliwości. W badaniach prezentowanych $\mathrm{w}$ niniejszym artykule nie chodziło o wyczerpująca

$\overline{\text { Zob. www.trenerpracy.pl/podsumowanie-i-roku-realizacii- }}$ projektu-centrum-dzwoni-ii-realizowanego-w-ramach-zadani
a-gotowi-do-pracy. Dostęp 7.05.2018 r. analizę możliwych miejsc płatnej i niepłatnej pracy wykonywanej przez osoby niepełnosprawne intelektualnie. Jakościowe badania na małej próbie przeprowadzono w Warszawie i mają one na celu ukazanie tych możliwości, które są dostępne w sytuacji zamieszkiwania w wielkim mieście. Głównym celem badań nie jest przedstawienie możliwych miejsc zatrudnienia, lecz przyjrzenie się subiektywnym odczuciom towarzyszacym osobom niepełnosprawnym jako byłym/obecnym/potencjalnym pracownikom.

\section{Dobór próby i organizacja badan}

Nie było łatwo znaleźć osoby, które miały jakiekolwiek doświadczenia związane $\mathrm{z}$ zatrudnieniem. Może się to wydać nieco dziwne, skoro powyżej stwierdzono, że centrum DZWONI udziela wsparcia zatrudnieniowego kilkudziesięciu osobom. Trudno je jednak odnaleźć. Po pierwsze dlatego, że wsparcie projektowe udzielane jest wielokrotnie tym samym osobom. Po drugie dlatego, że beneficjentem projektów może być osoba niepełnosprawna intelektualnie w stopniu lekkim: „posiada orzeczenie o stopniu niepełnosprawności znacznym lub umiarkowanym bądź lekkim, wydanym z uwagi na niepełnosprawność intelektualną lub spektrum autyzmu". Moim zdaniem jest to rodzaj „wykrętu”, za pomocą którego organizacje działające na rzecz osób upośledzonych umysłowo udzielają niekiedy wsparcia zatrudnieniowego osobom z innymi typami niepełnosprawności, bowiem lekki stopień niepełnosprawności intelektualnej przyczynia się do tego, że wskaźniki projektowe zatrudnienia mogą

${ }^{4}$ Zob. www.trenerpracy/rekrutacja/beneficjenci. Dostęp 7.05.2018 r. być łatwiej osiągnięte. W niniejszych analizach wzięto pod uwagę tylko osoby upośledzone umysłowo w stopniu umiarkowanym bądź znacznym.

Pierwszym etapem rekrutacji respondentów było przeprowadzenie ankiety wśród młodych osób upośledzonych umysłowo, zamieszkałych w Warszawie, na temat ich doświadczeń związanych z praca. Na ankiety odpowiedziało 100 respondentów dobranych zgodnie z metodą „kuli śnieżnej”: zidentyfikowany respondent rekomendował do badania osoby z kręgu swoich znajomych, spełniające kryteria doboru próby. Ankiety przeprowadzano wśród respondentów, co do których istniało przypuszczenie, że mogą mieć jakiekolwiek doświadczenie związane $\mathrm{z}$ zatrudnieniem. Okazało się jednak, że zdecydowana większość respondentów nie miała żadnych takich doświadczeń. Tak więc spośród 100 osób przebadanych za pomocą ankiety udało się zidentyfikować tylko 15 takich, które miały doświadczenia związane $\mathrm{z}$ zatrudnieniem. Pozostałych uczestników badania trzeba było rekrutować za pomocą odrębnych procedur. Nie do końca się to udało, dlatego próba badawcza składa się z dziewiętnastu, a nie jak pierwotnie planowano - dwudziestu osób.

Sytuację zawodową każdej z tych osób badano za pomocą wywiadów pogłębionych. Specyfika sytuacji badawczej polegała na tym, że rozmówcy to osoby upośledzone umysłowo, dlatego często komunikacja werbalna $\mathrm{z}$ nimi jest mocno utrudniona. Ponadto przedstawiane narracje są na ogół chaotyczne, pełne nieoczekiwanych skojarzeń niezwiązanych z tematem wywiadu. $Z$ drugiej jednak strony możliwość wysłuchania tych narracji daje 
wgląd w specyfikę sposobu myślenia osób badanych, ujawnia ich odczucia i emocje. Pozwala na uświadomienie sobie tego, w jaki sposób funkcjonują one w świecie społecznych sensów. W niektórych przypadkach było to bardzo poruszające.

Aby uzyskać w miarę "obiektywny” obraz sytuacji zawodowej osób badanych, ich narracje uzupełniono o wywiady z osobami z ich najbliższego otoczenia społecznego. Planowano do każdego z dziewiętnastu wywiadów dołączyć dwa inne, tak aby powstał możliwie wszechstronny opis sytuacji. W dwóch przypadkach to się nie udało. Tak więc w siedemnastu przypadkach sytuacja zawodowa danej osoby ujęta jest w trzech wywiadach (wywiad z samą tą osobą i dwiema osobami z jej otoczenia), natomiast w dwóch przypadkach do wywiadu z osobą niepełnosprawną dołączony jest jeden wywiad. W sumie daje to 55 wywiadów.

Taka procedura doboru rozmówców nazwana być może triangulacją. W jakościowych badaniach społecznych procedura triangulacji wykorzystywana jest dość często. Badacze stosujący tę procedurę na ogół mają na myśli albo triangulację technik zbierania danych $w$ badaniach etnograficznych (Angrosino 2010: 78), albo triangulację metod badania danego przypadku stosowaną przez badaczy zainteresowanych różnorodnością perspektyw badawczych (Stake 2009: 640). Możliwe jest też stosowanie triangulacji teorii, choć zdarza się to stosunkowo rzadko. Jak twierdzi Krzysztof Konecki (2007: 16), „triangulacja nie zawsze służy kontroli trafności, może być również stosowana jako poszukiwanie nowych warstw danych naświetlających problem badawczy z innej strony". Norman Denzin (2006: 254), który wprowadził triangulację do jakościowych badań społecznych, wysuwał „postulat powszechniejszego korzystania $\mathrm{z}$ «metody triangulacji», która może przyczynić się do przezwyciężenia stronniczych perspektyw i stworzenia pełnego obrazu".

Właśnie ta myśl Denzina, dotycząca przezwyciężania stronniczości, stała się inspiracją dla wprowadzenia w zaprojektowanych badaniach nowego rodzaju triangulacji, z którym jeszcze nie spotkałam się $\mathrm{w}$ badaniach społecznych, mianowicie triangulacji osób badanych. Badacze społeczni nie mają na ogół potrzeby sprawdzania wiarygodności rozmówców, bowiem badania jakościowe, wbrew neopozytywistycznemu zacietrzewieniu, nieomal nigdy nie są ukierunkowane na opis tego, ,jak faktycznie się rzeczy mają". Nieomal zawsze są one natomiast ukierunkowane na zapoznanie się z podmiotowym widzeniem wybranych aspektów rzeczywistości społecznej przez wybranych do badania aktorów społecznych. To zapośredniczenie, nazywane przez Anthony'ego Giddensa „podwójną hermeneutyką”, sprawia, że przedmiotem uwagi badacza staje się „obiektywnie istniejący” subiektywny świat wewnętrznych sensów. „Wszystkie nauki społeczne pozostają nieuchronnie hermeneutyczne w tym sensie, że możność opisania «co ktoś robi» w jakimkolwiek danym kontekście oznacza wiedzę o tym, co działający sam wie i wykorzystuje w konstruowaniu swojego działania. Wymaga to (zasadniczo) zdolności do «bycia na bieżąco», czyli wiedzy podzielanej [mutual knowledge] przez badanych i badających socjologów-obserwatorów" (Giddens 2001: 27).

Zaprezentowane powyżej poglądy Denzina i Giddensa odnoszą się do sytuacji, w których mamy do czynienia z kompetentnymi uczestnikami życia społecznego. $W$ zaprojektowanych badaniach kompetencje językowe uczestników badania stoją pod znakiem zapytania, podczas gdy ich kompetencje społeczne mogą stać się przedmiotem szczególnego namysłu. Dlatego też triangulacja osób badanych może stanowić procedurę, dzięki której skonfrontowane zostaną obrazy świata malowane przez osoby upośledzone umysłowo z „obiektywizującymi” opisami konstruowanymi przez kompetentnych użytkowników języka. Wzbogacenie wizji wybranego fragmentu rzeczywistości, w przypadku omawianych badań fragment ten stanowią doświadczenia związane z zatrudnieniem, to główny cel zastosowanej „triangulacji osób badanych”.

Badana próba była dosyć zróżnicowana. Oprócz dziewiętnastu osób niepełnosprawnych intelektualnie próba składała się z ośmiu matek, dwóch ojców (jeden z nich pełnił także rolę pracodawcy), trzech sióstr, dziewięciu terapeutów, czterech kierowników Warsztatów Terapii Zajęciowej, trzech psychologów, czterech przedstawicieli pracodawcy, dwóch asystentów osoby niepełnosprawnej, jednego trenera pracy. O ile dobór osób niepełnosprawnych przebiegał według powyżej przedstawionego schematu i może być nazwany próbą celową, o tyle wybór pozostałych osób, z którymi przeprowadzone zostały wywiady, był przypadkowy - były to dostępne osoby z najbliższego otoczenia społecznego danej osoby niepełnosprawnej.

Przy omawianiu wywiadów zostanie zastosowana następująca procedura oznaczania kolejnych przypadków:
Liczby od 1 do 19 - oznaczenie danego przypadku.

Litery:

a. osoba niepełnosprawna

b. matka

c. ojciec

d. siostra

e. terapeuta

kierownik WTZ

psycholog

h. przedstawiciel pracodawcy

i. asystent osoby niepełnosprawnej

j. trener pracy

Odrębnego omówienia wymaga kategoria „osoba niepełnosprawna intelektualnie”. Jest to kategoria bardzo niejednorodna. Tak jak trudno jest określić typowe cechy "normalnego" człowieka, tak też trudno jest sprowadzić do wspólnego mianownika typowe cechy osoby niepełnosprawnej intelektualnie. Tym, co łączy poszczególne osoby jest raczej wspólnota karier biograficznych polegająca na byciu pod czyjąś nieustanną opieką niż podobieństwo cech psychofizycznych. Prowadząc badania, nie zbierano danych metryczkowych, stąd brak wielu informacji o osobach badanych, które mogłyby być przydatne $\mathrm{w}$ przeprowadzanych analizach. $\mathrm{Z}$ treści wywiadów wynikają jednak pewne informacje, które każą przypuszczać, że w przypadku większej części badanych mamy do czynienia z niepełnosprawnością sprzężoną - oprócz niepełnosprawności intelektualnej w kilku przypadkach występuje padaczka, w jednym - schizofrenia, w kilku innych - niezidentyfikowana choroba czy niepełnosprawność (badani mówili o operacjach, trudnościach w poruszaniu się, niedosłuchu itp.). Można więc 
przypuszczać, że w wielu przypadkach upośledzenie umysłowe nie jest niepełnosprawnością „,wiodącą". Badani znaleźli się w sytuacji „bycia pod opieką" przede wszystkim z powodu innych niepełnosprawności, dlatego też ich funkcjonowanie intelektualne jest o wiele wyższe niż funkcjonowanie przeciętnej osoby niepełnosprawnej intelektualnie w stopniu umiarkowanym lub znacznym. W niektórych przypadkach poziom funkcjonowania intelektualnego wskazuje, że mamy do czynienia z niepełnosprawnością w stopniu lekkim.

Charakterystyczne dla badanej zbiorowości osób niepełnosprawnych jest to, że nie są to "typowe" osoby upośledzone umysłowo. Skoro spośród 100 przeprowadzonych ankiet nie udało się wyłonić więcej niż 15 osób mających jakiekolwiek doświadczenie związane z zatrudnieniem, to należy założyć, że "typowa” osoba upośledzona umysłowo w ogóle nigdy nie pracowała. Badana próba składa się więc z osób nietypowych, najlepiej funkcjonujących i z tego powodu często wybieranych do różnych projektów związanych z zatrudnieniem. Charakterystyczne jest, że zdecydowana większość osób badanych ma bardzo bogate doświadczenie z wieloletnim zatrudnieniem albo też wiele różnych doświadczeń z wieloma próbami krótkotrwałego zatrudnienia. Jeśli ktoś się „nadaje” do pracy, to często jest to kilka, wielokrotnie ponawianych prób. Takie osoby są szczególnie często „eksploatowane” w działaniach projektowych ukierunkowanych na zatrudnienie osób niepełnosprawnych intelektualnie - ponieważ inne upośledzone umysłowo osoby w ogóle się „nie nadają” do zatrudnienia. Ciekawe by było zbadać, na jakiej zasadzie funkcjonują bazy osób niepełnosprawnych intelektualnie, na pod- stawie których rekrutowane są osoby do kolejnych projektów.

Przeprowadzone badania mogą być potraktowane jako zbiorowe studium przypadku, które charakteryzuje się tym, że „pewna liczba przypadków jest badana w celu poznania pewnego ogólnego zjawiska" (Silverman 2008: 169). Jak pisze Stake (2009: 628), „poszczególne przypadki mogą, lecz nie muszą być znane zawczasu", w omawianych badaniach większość przypadków została zidentyfikowana wcześniej, podczas przeprowadzania ankiety, zaledwie cztery przypadki zostały dobrane dopiero $\mathrm{w}$ trakcie realizacji wywiadów. Taka procedura doboru osób badanych gwarantuje, że nie są one dobrane przypadkowo, lecz jest to próba celowa, na podstawie której można będzie formułować wiążące uogólnienia na temat doświadczeń związanych z zatrudnieniem osób upośledzonych umysłowo zamieszkałych w Warszawie i okolicach. Mała liczba zbadanych przypadków wynika z tego, że osób niepełnosprawnych intelektualnie jest $\mathrm{w}$ populacji bardzo mało - niespełna $1 \%$. Wobec tak małej liczebności populacji osób niepełnosprawnych intelektualnie uznać więc można, że zbadana próba wbrew pozorom - nie jest mała i w skali Warszawy odzwierciedla większość z możliwych do wyboru karier biograficznych związanych z zatrudnieniem.

Zastosowaną techniką badawczą był wywiad, który z pewnymi zastrzeżeniami można nazwać narracyjnym. Susan Chase twierdzi, że często wywiadem narracyjnym nazywa się wywiad odwołujący się do danych prozatorskich, czyli niemieszczących się w standaryzowanych narzędziach badawczych. Sama autorka określa wywiad narracyjny jako „amalgamat interdyscyplinarnych perspektyw analitycznych, rozmaitych podejść $\mathrm{w}$ ramach poszczególnych dyscyplin i zarówno tradycyjnych, jak też innowacyjnych metod - wszystkie one krążą wokół jednego tematu, jakim są konkretne elementy biografii, w takiej postaci, w jakiej opowiadają o nich ludzie je przeżywający" (Chase 2009: 16). W przeprowadzonych badaniach chodziło o wydobycie, przypomnienie sobie, opowiedzenie i zinterpretowanie przeżyć biograficznych związanych z różnorodnymi wydarzeniami skupionymi wokół kwestii zatrudnienia. Kwestie te w niektórych przypadkach łączyły się w zaskakujący sposób z innymi elementami biografii, tworząc nie dające się przewidzieć plamy znaczeniowe. Niekiedy sprawiało to wrażenie, że pozornie neutralne emocjonalnie wydarzenia mają ogromny wpływ na procesy tożsamościowe, a nawet mogą powodować kryzysy tożsamości. Narracje takie mogą pomóc czytelnikowi w uświadomieniu sobie trudnych, a nawet destrukcyjnych konsekwencji działań pozornie racjonalnych, służących dobru narratora. „Opowiadanie historii ludzi wykluczonych może pomóc stworzyć przestrzeń publiczna, wymagającą od innych, żeby usłyszeli to, czego nie chcą usłyszeć" (Denzin, Lincoln 2009: 4). Siłą danych zgromadzonych podczas prowadzenia wywiadów z osobami niepełnosprawnymi intelektualnie jest to, że mimo ubóstwa materiału informacyjnego, są one bogate $\mathrm{w}$ treści odnoszące się do uczuć i przeżyć, stanowią narracje na temat własnego miejsca na ziemi, poczucia lub braku poczucia sterowania własnym losem. W licznych badaniach dotyczących problematyki niepełnosprawności intelektualnej, zwłaszcza w stopniu umiarkowanym lub znacznym, głos tych osób słyszany jest niezmiernie rzadko.
Jean-Claude Kaufmann (2010: 14) wprowadza autorskie rozumienie pojęcia "wywiad rozumiejący". Autor twierdzi, że pojęcie to „należy rozumieć ściśle w sensie weberowskim, co znaczy, że doznanie wewnętrzne jest tylko instrumentem mającym na celu wyjaśnienie, nie zaś celem samym w sobie czy też samowystarczalnym rozumieniem intuicyjnym" (Kaufmann 2010: 14). W zaprojektowanych badaniach chodziło o to, aby dane uzyskane z wywiadów stały się podstawą stworzenia teorii mówiącej o prawidłowościach występujących $\mathrm{w}$ pewnych procesach społecznych, aby tworzona teoria była zakorzeniona w „faktach”, czyli, mówiąc słowami Anzelma Straussa, stanowiła wersję teorii ugruntowanej (Glaser, Strauss 2009). Teoria ta dotyczyć będzie z jednej strony prawidłowości występujących w przebiegu karier biograficznych związanych z zatrudnieniem, $\mathrm{z}$ drugiej strony - procesów tożsamościowych związanych ze specyfiką pełnienia roli społecznej pracownika, która jest jedną z podstawowych ról konstytuujących społeczne funkcjonowanie człowieka dorosłego.

\section{Analiza wyników}

Spośród dziewiętnastu osób w chwili badania pracowało 11, w jednym przypadku wiadomo, że osoba 15a utraciła pracę wkrótce po przeprowadzeniu badań, czego zresztą należało się spodziewać na podstawie wypowiedzi zarówno samej tej osoby, jak i osób, które o niej opowiadały. Osiem osób pozostawało bez pracy.

Niezależnie od aktualnego statusu na rynku pracy, trudno jest jednoznacznie określić, czy dana osoba chce pracować. Standardowo przyjmuje się, że ludzie potrafią udzielić wiążącej odpowiedzi na proste 
pytanie: „Czy chce pan/pani pracować?”. W przypadku osób niepełnosprawnych intelektualnie sprawa ta nie jestjednak prosta z trzech zasadniczych powodów. Po pierwsze, zdarza się, że osoba niepełnosprawna ma na ten temat inne zdanie niż rodzice/terapeuci i nie wiadomo, która z tych opinii jest bliższa prawdy. Po drugie, osoba niepełnosprawna nie zawsze rozumie słowo „pracować" w standardowy sposób. Po trzecie wreszcie, deklarowana chęć pracy może daleko wykraczać poza realne możliwości zatrudnienia. $W$ przeprowadzonych analizach staram się zwracać uwagę na wszystkie trzy z wymienionych aspektów.

Spośród ośmiu osób niepracujących dwie deklarują chęć zatrudnienia, pozostałe pięć osób nie chce, a jedna nie może (ze względu na zaostrzający się przebieg choroby psychicznej, przypadek 10a) pracować. Natomiast spośród jedenastu osób pracujących tylko jedna nie wyraża chęci dalszego zatrudnienia oraz jedna osoba, mimo chęci dalszej pracy, traci jednak zatrudnienie (przypadek $15 \mathrm{a}$ ). W poniższych analizach jako studia przypadków zostaną opisane te osoby, których doświadczenia związane z zatrudnieniem mogą być traktowane jako soczewka skupiająca w sobie promienie światła oświetlające biografie innych ludzi znajdujących się w analogicznych sytuacjach życiowych.

\section{Deklarowana chęć pracowania wśród osób} niepracujących

Pan Tomek ${ }^{5}$ (przypadek 1a) obecnie nie pracuje, chce pracować, ale widzi ku temu poważne przeszkody.
Chciałbym pracować dalej, tylko czasami jest tak, że zimą to trochę tak daleko jest do pracy. [...] Ja bym chciał iść w kierunku muzyki, ale to nie jest realne niestety. W swoim kierunku nie mogę iść, no bo gdzie ja teraz znajdę pracę jako didżej. [...] Tak myślałem ogólnie, że mógłbym pracować na dworze. Ale ogólnie ciągnie mnie do fotografii. W kierunku fotografii chcę iść, ale to też jest, albo się zrobi dobre zdjęcie, albo złe. [...] Odzywali się do mamy, ale też o piątej rano wstawać i tutaj dojeżdżać na szóstą. Tutaj na dwie zmiany, od dwudziestej do szóstej rano. Pewnie bym to zdrowiem przypłacił tylko. (1a)

W wypowiedziach Tomka widać pewnego typu rozdarcie: „teoretycznie” chciałby pracować, jednak praca realnie dla niego dostępna nie leży w kręgu jego zainteresowań, natomiast praca wymarzona jest zupełnie poza jego możliwościami. Potencjalni pracodawcy nie kontaktują się bezpośrednio z nim, lecz z mamą i to mama steruje jego karierą zawodowa. Prawdopodobnie pod jej wpływem Tomek czuje się zniechęcony do pracy, jaka może mu być zaproponowana. Mama negatywnie ocenia proponowane Tomkowi zajęcia:

Ostatnio Tomek dostał propozycje pracy w sklepie spożywczym do sprzątania, do uzupełniania lodówek i tak dalej. Ale to była praca od godziny szóstej do godziny trzynastej, i od trzynastej do dwudziestej. Na dwie zmiany. To nie wchodzi w grę, bo o godzinie szóstej to on bierze leki. I o której on by musiał wstać do tej pracy, żeby dojechać z jednego końca miasta na drugi, gdzie był ten sklep? [...] Przy jego stanie zdrowia to w ogóle nie wchodzi w grę. To nie są warunki pracy dla takich chorych ludzi. Praca na godzinę szóstą to jest praca dla zdrowych ludzi. My odrzucamy wszystkie te pro- pozycje. Panie [trenerki pracy - przyp. EZM] owszem, tam się starają, tylko panie mają podejście czysto merytoryczne do tego, na papierze wszystko jest możliwe i wydaje im się, że to jest prosta sprawa. Natomiast my [matki - przyp. EZM] mamy to w życiu i wiemy, jak wygląda sytuacja naszych dzieci i co one mogą, czemu dadzą radę, w czym są dobre, jak mogą pracować. Narzucanie im pracy takiej czy innej w ogóle nie wchodzi $\mathrm{w}$ grę. Nie jest to takie proste. (1b)

Psycholog z Warsztatu Terapii Zajęciowej (WTZ), do którego uczęszcza Tomek, potwierdza hamujący wpływ rodziców na motywację do pracy Tomka:

On jest chętny chyba do pracy nadal. [...] Tylko nie wiem, na ile jest ta ingerencja rodziców. Więc mogą go trochę hamować w tym. Rodzice nie są chętni, wydaje mi się, trochę się boją jego jakichś frustracji, że może coś tam mu się nie uda, że jakieś problemy z rentą, że jakaś nowa sytuacja i że będzie przeżywał i nie dadzą sobie z nim rady. No tak myślę. Że go będą wykorzystywać, tego się jeszcze rodzice boją. [...] Myślę, że on jak najbardziej by się nadawał do pracy. No na pewno cały etat nie, dla żadnego z nich tutaj. (1g)

Doświadczenia związane $\mathrm{z}$ pracą $\mathrm{z}$ jednej strony wzbogaciły Tomka, on sam mówi z dumą:

Najpierw miałem praktyki, ale już później po praktykach umowę ze mną podpisali. Już była normalna pensja, ale pensja taka, że wszystko szło na konto, nie na rękę. Bo ja na rękę to bym zaraz zgubił. To wszystko szło na konto. Przelewem. (1a)

Pozytywny wpływ pracy potwierdza również pani psycholog:
Miał większe poczucie własnej wartości. W cudzysłowie powiedzieć można, że wydoroślał bardziej. Taki się poczuł dorosły, lepszy, bardziej wartościowy, że pracował i że jest w stanie jednak pracować. (1g)

Jednak z drugiej strony doświadczenie związane $\mathrm{z}$ zatrudnieniem zaburzyło dotychczasowe funkcjonowanie Tomka, a po utracie pracy powrót do starej rutyny był dla niego trudny i w pewnym sensie degradujący:

Jak przyszedł do warsztatu, przez jakiś czas tutaj bardzo był taki bierny. Ten warsztat jest czymś gorszym, że co on tam może robić, jak on pracował już. Pewnych rzeczy nie chciał wykonywać. Na pewno dla niego to było takim policzkiem. Nie wiem, jak to powiedzieć. Że on spadł z tego piedestału, gdzie tam pracował, a teraz znowu jest w warsztacie. Mówit, że on tu długo nie pobędzie i że znowu będzie sobie szukał pracy. Kiedyś bardziej miał takie ambicje nierealistyczne. Teraz trochę mniej, może po tej pracy. Oczywiście miał spadek nastroju, później znowu zaczął być taki jakby aktywny i chyba lepiej funkcjonuje niż kiedyś. Oczywiście ma czasami jakieś takie swoje marzenia, że będzie didżejem. (1g)

Sytuacja zawodowa Tomka, opisana tu z konieczności w sposób bardzo skrótowy, ukazuje dylematy egzystencjalne, na które jest on narażony. Tomek funkcjonuje z jednej strony jako niezaradne dziecko swoich rodziców, którzy antycypując jego niepowodzenia, wolą „,na wszelki wypadek” nie narażać go na dyskomfort ewentualnych porażek. Z drugiej strony trenerzy pracy i terapeuci z WTZ - jak można wywnioskować $\mathrm{z}$ wypowiedzi pani psycholog - motywują go do podjęcia zatrudnienia, do czego 
ich zdaniem Tomek się świetnie nadaje mimo braku umiejętności pisania i czytania. Marzenia Tomka o podjęciu pracy didżeja czy fotografa mają, jak można sądzić, charakter ucieczkowy, są odskocznią od realnego świata, w którym niezaspokojone ambicje zawodowe napełniają go goryczą i nie pozwalają mu cieszyć się życiem takim, jakie ono jest.

Pan Roman (przypadek 8a) jest osobą bardzo słabo komunikującą się. Wypowiada pojedyncze wyrazy, często trudno się zorientować, co ma na myśli. Na pytanie, czy chciałby pracować, odpowiada:

W urzędzie, u burmistrza. Chciałbym być dyrektorem, burmistrzem, przewodnikiem wycieczek. [...] Chciałbym pójść na kurs masowania pleców. Mama mi mówiła. Tak bym mógł zarobić, godzinowa praca, wystarczy 12 godzin. Mógłbym dla siebie zarobić, chciałbym zarobić. Mama chciała ze mną na wczasy pojechać, ale trzeba kurs zdać. Tak to by siedziała w domu, lepiej żeby pojechała na wczasy. (8a)

Z wypowiedzi Romana wynika, że ewentualnej przyszłej pracy nie traktuje $\mathrm{w}$ kategoriach realnie istniejącej perspektywy. To są raczej jego marzenia skonfrontowane $\mathrm{z}$ wyobrażeniami mamy na temat jego możliwości zawodowych. Wydaje się, że i jedno, i drugie to dla Romana zbyt odległe i abstrakcyjne możliwości. Wcześniej Roman pracował w trzech różnych miejscach: w firmie cukierniczej, w piekarni, w Pizza Hut. Na pytanie, czy chciałby pracować w Pizza Hut, odpowiada:

Za wcześnie dla mnie. Trzeba wstać za piętnaście piąta. Miałbym ochotę kupić ośrodek, muszę z kadrą porozmawiać. Chcę pracować.
Mama pana Romana, kobieta 87-letnia, opowiada o czternastoletnim zatrudnieniu syna $\mathrm{w}$ kilku zakładach pracy chronionej, aż do ich zlikwidowania. Obecnie syn nie pracuje, lecz ciągle ma nadzieję na dalsze zatrudnienie.

On czeka, że zmieni się rząd i zacznie pracować. [...] Praca dla niego konieczna, praca leczy nerwy. Czeka na to, jak rządy się zmienią, czeka na pracę, to jest jego marzenie. [...] On by chciał stemplować, porządkować. Ma ślicznie poukładane. Do przesady czysty, tego prania tyle. [...] On do każdej pracy się dostosuje, każdą pracę będzie pracował. (8b)

Jednak w odpowiedzi na pytanie, jaki wpływ miała praca na funkcjonowanie Romana, wypowiedzi mamy nie są już tak optymistyczne:

Mówił tak wyraźnie, nie był nerwowy, można z nim było porozmawiać. Kto z kim przestaje, takim się staje. Roman to ginie. Jest bardzo wrażliwy. Jest biedny z tą swoją chorobą [zespół Downa - przyp. EZM], ma specyficzną urodę, to mu dokuczali.

Terapeutka potwierdza nierealistyczne oczekiwania pana Romana związane z zatrudnieniem:

Na pewno chciałby pracować, ale na własnych zasadach, „przyjdę, kiedy przyjdę”. Najchętniej chciałby przystawiać pieczątki jako burmistrz. Raczej wyższe stanowiska. Chciałby być kimś ważnym, dyrygować kimś. [...] Roman nie uważa, że jest niepełnosprawny, chyba że trzeba wywalczyć miejsce w autobusie dla siebie, to wtedy jest biedny i chory, to mu się należy. Jeżeli chodzi o pracę, to nie widzi przeszkód, żeby być dyrektorem. Po rozmowie z panią już zaczął na- wet mówić, „Super, będę w kadrach pracować". Teraz przez parę tygodni będziemy pracować nad tym, by zrozumiał, że to był tylko wywiad, że burmistrz będzie ten sam. Jest jednym z niewielu uczestników, którzy wykazują potrzebę pracy. (8e)

Doświadczenia związane z zatrudnieniem z jednej strony wzbogaciły Romana, jednak z drugiej strony pozostawiły żal i rozgoryczenie - podobnie jak to miało miejsce u pana Tomka.

Pracował w pizzerii, w piekarni, bardzo różnie o tym opowiada. Czasami mówi o tym pozytywnie, że pracował, miał własne pieniądze, czuł się ważny. Niektóre wypowiedzi, które są dla niego nieprzyjemne, że ktoś mu zwracał uwagę, że coś się działo..., nie do końca wie, co mu się nie podobało. Były problemy, gdyż Roman ma problem z punktualnościa, nie zna się na zegarku, nie ma poczucia czasu. [...] Nie wiem, dlaczego go zwolnili, nie da się tego wyciagnnąć ani od mamy, ani od Romana. Mama nie mówi, że może mieć problemy w komunikacji ogólnoludzkiej w sensie współpracy, nawiązania bliższych relacji. Też tak mogło być. Mama opowiada o osobach, które go zaczepiały, robiły mu na złość, w przekonaniu Romana. Ale może być, że to nie tak. Roman konfabuluje, potrafi zaleźć za skórę.

Terapeutka uważa jednak, że Roman nadaje się do pracy i przy odpowiednim wsparciu mógłby podjąć satysfakcjonujące zatrudnienie.

Sprawdzałby się spokojnie w restauracji, sprzątając, czyszcząc stoliki. Mógłby robić takie rzeczy. Gdyby ktoś go zatrudnił na raz w tygodniu w biurze, to na pewno miałby bardzo czysto. $\mathrm{W}$ dużym supermar- kecie, gdzie jest duża przestrzeń, to raczej nie. Jemu trzeba pokazać, co ma zrobić. To musiałoby być coś małego.

Terapeutka w realistyczny sposób ocenia możliwości zatrudnienia pana Romana w małym, przyjaznym otoczeniu, przy łatwych pracach, dostosowanych do poziomu jego umiejętności, w niewielkim wymiarze czasu pracy. Nie sądzi, aby tego typu zatrudnienie wiązało się $\mathrm{z}$ jakimiś zagrożeniami. Przeciwnego zdania są jednak pan Roman i jego mama, którzy obawiają się - zgodnie ze słowami terapeutki - utraty świadczeń socjalnych: „lęk przed utratą tego, co już ma, utratą renty. Jeżeli będzie pracował, to będzie miał dochód, a jeśli straci pracę, to wtedy nic nie będzie miał." Terapeutka wypowiada się także ogólnie na temat zatrudniania osób niepełnosprawnych intelektualnie na otwartym rynku pracy:

Osoby niepełnosprawne powinny być zatrudniane tam, gdzie sobie radzą. Bardzo często robi się im krzywdę, zatrudniając ich tam, gdzie sobie nie radzą. Pojawia się frustracja skojarzona z pracą. Kilku uczestników mamy, którzy pracowali. Gdzieś byli źle traktowani, rodzice nie chca ponownie przechodzić tego, że dana osoba wracała z płaczem. Bo miało być fajnie, miała mieć pracę, a przychodziła, że tak powiem, zdołowana. Trzeba przemyśleć to, czy by się sprawdziła.

Kariera zawodowa Romana wskazuje na to, że wieloletnia praca w małych zakładach pracy świadczy o jego możliwościach sprostania wymaganiom pracodawców. Ostatnia praca w Pizza Hut była pod tym względem najmniej udana i być może złe wspomnie- 
nia rzutują w dużej mierze na niemożność podjęcia decyzji o rozpoczęciu kolejnej konkretnej pracy na miarę własnych możliwości. Z drugiej strony pan Roman jest osobą w wieku około pięćdziesięciu lat i być może jest to główny powód, dla którego praca pozostaje jedynie $\mathrm{w}$ sferze marzeń, a nie konkretnych planów, gdyż osoby zespołem Downa starzeją się szybciej niż reszta populacji (Ochman 2014: 155).

\section{Deklarowana chęć niepracowania wśród osób niepracujących}

Pozostałe osoby niepracujące nie wyrażają chęci zmiany swojego statusu. Wszystkie z tych osób mają bogate doświadczenia związane z zatrudnieniem: część podejmowała wiele prób krótkotrwałego zatrudnienia - wywiady numer 2, 3, 4, 10; natomiast dwie osoby przez wiele lat pracowały w jednym miejscu - wywiady 14 (10 lat, jako jeden z nielicznych wypracował emeryturę), 17 (15 lat pracy). Ciekawy jest przypadek pani Ewy (przypadek 10a), która twierdzi, że chciałaby pracować gdyby była zdrowa, jednak zdaje sobie sprawę z tego, że choroba uniemożliwia jej spełnienie tego marzenia:

No mogłabym pracować, chciałabym, pewnie. Zawsze bym coś robiła, coś bym się nauczyła. [...] Chciałabym być zdrowa. Wtedy mogłabym dorobić sobie do renty na przykład. Ale czy to można w ogóle? Czy to jest możliwe?

Natomiast kierownik WTZ ma na ten temat zupełnie odmienne zdanie:

Ewa jest ultraniedokładna, szybko się męczy. Interesują ją sprawy związane z nią bezpośrednio, czyli związki, nie związki, miłości i takie tam. Tak że ona się nie nadaje do pracy. Chciałaby mieć kasę i żeby najlepiej nikt od niej nic nie oczekiwal. No ale to tak się nie da. [...] Zawsze była gdzieś w swoich odlotach. Kiepsko się z kimś takim pracuje. Mając takiego pracownika, wolałbym to sam milion razy zrobić niż oczekiwać od niej dokładności i wykonania zadania jakiegokolwiek. Bo to by się wiązało z frustracją jej i pracodawcy. (10f)

Kierownik mówi też, że na podstawie wieloletniego doświadczenia w pracy w WTZ, wyrobił sobie zdanie na temat zatrudniania osób niepełnosprawnych intelektualnie:

Jesteśmy w WTZ, czyli placówce, która przygotowuje ich do podjęcia pracy na otwartym rynku pracy. Więc tutaj nie powinny być osoby, które nie nadają się do pracy. Z drugiej strony tak samo nie ma placówek dla takich osób jak Ewa, więc jest tutaj. Jeśli ktoś będzie miał takie miejsce pracy, w którym będzie miał osobę, która czasami może nie przyjść do pracy, bo ma gorszy dzień, to Ewa jest właśnie takim pracownikiem. [...] My też się staramy, ale materiał jest, jaki jest. Jeżeli ktoś mi powie, że jesteśmy nieskuteczni, bo nie wysyłamy ludzi w świat, no to ja powiem, że bardzo chętnie ich wyślemy w świat, jeżeli te stanowiska będą dostosowane do ich potrzeb, a nie sa. PFRON daje sporo pieniędzy, z tego co się orientuje, na przygotowanie takiego stanowiska. Pomaga przez pewien czas utrzymać taką osobę na stanowisku. W momencie gdy odsuwa się to wsparcie, no to pracodawca szybko się orientuje, że taka osoba jest nierentowna absolutnie. (10f)

Osoby, które mają za sobą wiele różnych, lecz krótkotrwałych „incydentów” zatrudnienia, to benefi- cjenci różnych projektów związanych z aktywizacją zawodową osób niepełnosprawnych. Przykładowo:

Jola była często aktywizowana zawodowo, ponieważ jest taką osobą dość sprawną, chętną do pracy, uspołecznioną, więc różne typy kursów, szkoleń, warsztatów, pisania CV i w ogóle współpracy z jakimiś fundacjami, które robią tą całą aktywizację zawodową. To ona zawsze była chętna do tego i miała różne też praktyki. Te praktyki nie zawsze jej dobrze szły, nie zawsze była zadowolona. $(2 \mathrm{~g})$

Robert przed podjęciem praktyk chodził na kursy, miał kilkanaście godzin kursów. Później miał praktyki, dwa razy po miesiącu, a później trzy miesiące. Jak przyszło do tego, żeby miał staż, to podziękowali, powiedzieli, że wolą zatrudnić osoby pełnosprawne [śmiech]. Była przerwa, później znowu kurs i pracował w [firmie x], później znowu przerwa i znaleźli mu staż na poczcie. Trzy miesiące, a jak przyszło do zatrudnienia, nie ma, bo wola pełnosprawnych [śmiech]. [...] Odczekał miesiąc czy dwa i znowu miał praktykę, po tej praktyce przyjęli go na czas określony, przedłużyli mu o miesiąc, przepracował tam w sumie osiem miesięcy. (4b)

Wszystkie cztery osoby badane, które miały podobny przebieg kariery zawodowej, słowo „praca” rozumieją w specyficznym sensie. Praca to przede wszystkim przebywanie w zakładzie pracy i odbywanie tam praktyk czy staży, najprawdopodobniej w „systemie projektowym”. Kolejne próby zatrudnienia nie stanowią zaplanowanych etapów kariery, lecz są przypadkowymi incydentami wynikającymi z „dostania się" do akurat realizowanego projektu.
Można odnieść wrażenie, że celem osób czy organizacji realizujących projekty jest przede wszystkim wypracowanie wskaźników projektowych, natomiast osoby realizujące te cele traktowane są raczej instrumentalnie. Wielość przypadkowych, niepowiązanych ze sobą prób zatrudnienia ma najczęściej negatywne skutki i wywołuje złe skojarzenia z pracą. Przykładowo:

Na pewno jak zaczęła pracować, była bardzo z tego dumna, że zarabia pieniądze, że się tam gdzieś zaangażowała. No ale też miała różne problemy. [...] Ona się teraz trochę zmieniła, nie wiem czy pod wpływem zatrudnienia. Na pewno jest teraz bardziej sfrustrowana, widzi, że pewne rzeczy jej się nie udaja. [...] Na pewno zmieniło się właśnie to, że jest bardziej sfrustrowana, bardziej chodzi o to, że sobie z czymś nie dawała rady. To, to jest taka frustracja. (2g)

Chyba ja nie usłyszałam nic dobrego. Ona ma bardzo negatywne wspomnienia, nieprzyjemne. To po prostu jej zaburzyło chyba wszystko. Myślę, że były jakieś dobre rzeczy, ale ona tego nie pamięta. Ona pamięta tylko to, że było niedobrze, że na nią krzyczał, no i została zwolniona. (3e2)

On może się trochę cofnął dlatego, że się zraził i po trosze się zamknął w sobie. Przez miesiąc, przez dwa miesiące było pięknie, ładnie, a później coraz częściej: ",Mamo, nie będę chodzi1”, ,Dlaczego?”, ,"Bo nie będę". Ciężko było z niego wyciągnać cokolwiek. Dopiero później tamte babki mi powiedziały. Siedział i płakał [cisza]. No i oczywiście klął. [...] Obiecują góry przy zatrudnieniu, a później to się wyżywają, krzycza, jedno na drugie donosi. (4b) 
Kolejną wspólną cechą analizowanych przypadków jest podkreślanie niefunkcjonalności szkoleń i braku związku między szkoleniami a praca.

Myślę sobie, że te wszystkie szkolenia są bez sensu, skoro mają być to tylko szkolenia. Jeśli ma być szkolenie, które ma ją przygotować do podjęcia konkretnej pracy, to miałoby sens. Natomiast tak, to... Nie wiem, robią nadzieję, nic nie dają. Nic z tego nie wynika. Bo kolejne szkolenie jak pisać $\mathrm{CV}$ i jak się szuka pracy to jest nietrafione szkolenie. (3e2)

Były warsztaty takie siedmiodniowe, co też mam wrażenie nie do końca jest przemyślane. Wytrzymać siedem godzin przez siedem dni codziennie zajęć warsztatowych, gdzie było pisanie, rozmawianie, prace na materiałach papierowych, odgrywanie scenek, w każdym razie praca wymagająca dużego wysiłku intelektualnego i dużej koncentracji. I wytrzymać to dla naszych upośledzonych umysłowo uczestników, to jest chyba aktem jakimś heroicznym, bo ja byłam zmęczona, a co dopiero oni. Ale taki był program, tak to zrobiliśmy, poszło. (17j)

Zaczęły się poszukiwania tych różnych fundacji, zaczęło się od Centrum DZWONI, gdzie były właśnie jakieś szkolenia, w międzyczasie był też Caritas. To było takie przygotowanie do tego, jak napisać $\mathrm{CV}$, jak się poruszać po rynku pracy, jak szukać w Internecie ofert pracy. Ale wiadomo, to do niczego nie prowadzi. Nic. To znaczy wydaje mi się, że oni teoretycznie wykonują jakieś zadania, jakieś papiery wypełniaja, ale praktycznie na tym się to kończy. (19d)

Rodzice osób niepełnosprawnych intelektualnie $\mathrm{w}$ przeważającej mierze nie chca, aby ich dzieci pra- cowały. Jedna z terapeutek mówi o tym następująco:

Rodzice mają takie czasami wyobrażenie duże o możliwościach dziecka i jak słyszą, że dziecko miałoby pracować gdzieś przy sprzątaniu, porządkowaniu terenu, to nie chca. [...] Generalnie nie chcą żeby dzieci pracowały. W ogóle, żadną pracę niechętnie. Tu kiedyś były panie z Centrum DZWONI, to zostało na spotkaniu z tymi paniami, nie wiem, dwoje czy troje rodziców. Nikt nie jest tak mocno zainteresowany podejmowaniem pracy. No są też lęki: utrata zasiłku, renty. (4e)

W połączeniu z tym, że rynek pracy dla osób niepełnosprawnych intelektualnie praktycznie nie istnieje, perspektywa zatrudnienia tych osób na satysfakcjonującym stanowisku pracy jest raczej nierealna. Należy przy tym pamiętać, że przeprowadzano wywiady z osobami mającymi doświadczenia związane $\mathrm{z}$ zatrudnieniem, podczas gdy przytłaczająca większość osób niepełnosprawnych intelektualnie w ogóle takich doświadczeń nie miała.

W badanej grupie znalazły się dwie osoby legitymizujące się długoletnim zatrudnieniem. Każda z tych osób oprócz upośledzenia umysłowego posiada inną dysfunkcję - słuchu (14a) i wzroku (17a), można więc przypuścić, że upośledzenie umysłowe jest „wtórną" niepełnosprawnością, a więc osoby te pod względem intelektualnym funkcjonują lepiej niż większość pozostałych osób. Drugą wspólną cechą ich biografii jest pozostawanie pod czujna opieką rodziców: praca w Zakładzie Pracy Chronionej wspólnie z rodzicami (17); bardzo silny związek emocjonalny z mamą (14). Obydwie te osoby są w wieku około 50 lat, a więc brak chęci dalszego zatrudnienia prawdopodobnie wynika z obniżenia sił witalnych i chęci odpoczynku po wielu przepracowanych latach. Rodzice w obu przypadkach są zdecydowanie przeciwni dalszemu zatrudnieniu. Trener pracy nazywa niechęć do podjęcia zatrudnienia osoby 17a „przykładem porażki”, gdyż jest to osoba szczególnie dobrze funkcjonująca. Niemniej jednak można uznać, że kariery biograficzne obu osób mają wydźwięk pozytywny i świadczą o tym, że w sprzyjających okolicznościach niektóre, szczególnie dobrze funkcjonujące, osoby niepełnosprawne intelektualnie mogą wieść satysfakcjonujące życie zawodowe.

\section{Deklarowana chęć niepracowania wśród osób pracujących}

Niemal wszystkie osoby pracujące wyrażają chęć dalszego pozostawania $\mathrm{w}$ zatrudnieniu. Jest tylko jeden wyjątek, który omówię poniżej. Analizowany przypadek jest wstrząsającym dokumentem ukazującym, w jak dramatyczny sposób postrzeganie świata przez osobę niepełnosprawną intelektualnie może się różnić od wizji świata jej rodziców.

Pani Magda (przypadek 11a) podczas przeprowadzania wywiadu czuje się niekomfortowo, nie chce rozmawiać o pracy. Po każdym pytaniu badaczki następuje długa przerwa. Odnosi się wrażenie, że Magda jest zmuszana do udziału w badaniu przez matkę, która jest obecna podczas rozmowy i naciska na udzielanie odpowiedzi, niektóre pytania sama zadaje. Fragment dialogu z początku wywiadu:

Badacz: Denerwujesz się troszkę?

Magda: Trochę.
Badacz: Trochę? A co mogłabym zrobić, żebyś się mniej denerwowała?

Magda: Nie wiem [cisza].

Mama: Może ja wyjdę?

Magda: Nie.

Mama: Będzie jej raźniej wtedy.

Magda: Nie.

Mama: No to Misiu, powiedz nam.

Magda: Nie chcę opowiadać o pracy [długa cisza].

Mama: A powiedz jeszcze, jakie doświadczenia masz w ogóle związane z praca. Może od tego zacznij. Magda: Doświadczenia?

Mama: No, może od tego zacznij i powoli przejdziesz do innego, do innej pracy. Będziesz mogła powiedzieć, czym się różni jedna praca od drugiej.

Magda: [długa cisza] Tak.

Badacz: Zgodzisz się?

Magda: Tak.

Po zakończeniu wywiadu, gdy badaczka podziękowała już za rozmowę, Magda dodaje: „Przepraszam, mama mówiła, że mam z panią rozmawiać ooo... o modzie mamy rozmawiać, nie o pracy". Matka jest zakłopotana, badaczka skonsternowana, wygląda na to, że Magda została skłoniona przez matkę do udziału w badaniu podstępem. Matka jest dumna z tego, że córka pracuje, uważa, że praca bardzo pozytywnie na nią wpłynęła i Magda „zmieniła się na lepsze" (11b), dlatego, jak się wydaje, udział córki w badaniu uznaje za wyróżnienie.

Magda opowiada o wykonywanej pracy bardzo zdawkowo, nie wie dokładnie, na czym polegają powierzone jej zadania: „Ta praca polega na... to praca biurowa [cisza], która wymaga dużych... wymagania [długa cisza]". Na prośbę badaczki o konkrety 
Magda odpowiada:

To jest wielki biurowiec. Taka firma, taka sprzedażowa. Ta praca zajmuje się głównie narzędziami sprzedaży. [...] Ja archiwizuję dokumenty. Czyli to jest taka praca [przerwa] biurowa, czyli przy biurku. Ja pracuję razem z kelnerem. Razem ze skanerem [myli słowa] [...]. Bo nasza praca to ja archiwizuję różne dokumenty.

Matka: No to opowiedz, na czym polega ta twoja praca, na czym polega archiwizacja. A potem przejdziemy dalej.

Magda: Dobrze. Moja praca polega na tym, że są [cisza] dokumenty. Żół... żółto, biało-żółto-różowo dokumenty. To raz jak skanuje, to mam białe dokumenty. A są takie dokumenty, które są różowe.

Badacz: I z tymi różowymi co się robi?

Magda: Różowymi kiedyś miałam. Ale to nie był papier. Na biały. Ale zmienili papier.

Badacz: Yhm. I teraz jest tylko biały? Dobrze zrozumiałam?

Magda: Tak. Ale czasami są różowe albo żółte. I tego się nie skanuje. Ja skanuję tylko Wzetki ZO. [...] Bo ja mam tam magazyn i tam mi wydawają pudła. $Z$ sygnaturami.

Badacz: Rozumiem. A czy oprócz skanowania masz jeszcze jakieś obowiązki?

Magda: Nie. Tylko skanowanie.

Z wypowiedzi Magdy można wywnioskować, że nie pracuje samodzielnie. Pomaga jej kolega, który zna jej hasło do komputera oraz osoba, którą nazywa opiekunką. „Opiekunka to jest na zlecenie mojego taty". Okazuje się, że Magda jest zatrudniona w firmie, w której jej ojciec jest dyrektorem. Pracuje tam też jej wujek. Magda nie chce, aby ojciec słyszał jej wypowiedzi, prosi o zamknięcie drzwi: „niestety, pracuję w taty firmie".

Badacz: No i jak tam ci jest? Lubisz czy nie bardzo? Magda: Tak pół na pół.

Badacz: Zacznijmy od tego, co jest fajne w pracy, co ci się podoba.

Magda: Nie mam takich rzeczy.

Mama: To jak pół na pół, to jak to?

Magda: Można powiedzieć, że mam najlepszą przyjaciółkę.

Magda opowiada, jak pije kawę z panią z kadr, jak obchodzi w pracy imieniny i urodziny - przynosi ciasto i tym podobne. Czyli „prywatyzuje” prace i jako jedyny pozytyw ukazuje w pracy to, co niepodobne do pracy, a przypomina stosunki towarzyskie. $Z$ drugiej strony relacje społeczne stanowią problem, który sprawia, iż Magda jest wyobcowana, nie jest członkiem zespołu pracowniczego. Mówi o tym słowami, których zdaje się nie rozumieć:

Jest tylko jedna sprawa, którą niestety na tym się przylizgnęłam [matka ją poprawia]. Poślizgnęłam się. To podpuszczanie innych i zła komunikacja. [...] Komunikacja jest taka, że nie umią rozmawiać z innymi działami, oni są raczej niekomunikacyjni. Nie potrafią rozmawiać, tylko się zawsze kłócą albo robią sensację. Czasem rozmawiają, czasem mają spotkania. Jak obserwuję przez drzwi, to czasami widzę, że są trochę zdenerwowani, jak ich tam obserwuję... znienacka.

Z słów tych wynika, że Magda nie uczestniczy $\mathrm{w}$ spotkaniach pracowniczych, rolę zewnętrznego obserwatora traktuje jako coś oczywistego. Badacz-

ka pyta o szczegóły relacji społecznych:
Badacz: Powiedziałaś, że masz dwójkę ludzi do pomocy. A jak z resztą pracowników? Czujesz, że oni są przyjaźnie do ciebie nastawieni czy nie do końca? Magda: No to ja mam różne zdanie na ten temat. I chciałabym nie wtykać się $\mathrm{w}$ nie własne sprawy i szczególnie o tym nie rozmawiać.

Magda podaje kilka przykładów, z których wynika, że koledzy z pracy traktują ją jak „piąte koło u wozu", wygłaszają złośliwe, niesympatyczne komentarze pod jej adresem.

Kolejny wątek podjęty przez badaczkę to przebieg zatrudnienia:

Badacz: Czyli pracujesz już kawałek czasu.

Magda: No niestety.

Badacz: Czyli co? Czy dobrze rozumiem, że nie za bardzo chcesz tam pracować?

Magda: Dokładnie.

Badacz: Chciałabyś zmienić pracę czy w ogóle odpocząc od pracy całkowicie?

Magda: Całkowicie odpocząć. Bo tak jak widzę, to ta praca mnie wykończy. [...] Ciągle wszyscy mówią mi, że jestem uchem, że wszystko słyszę. Ja myślę, że wykorzystują mnie psychicznie. Mówia, obmawiają. Badacz: Po prostu są nieprzyjaźni dla ciebie? Tak? Magda: Nie, no nie w tym rzecz [zdenerwowanie]. W tym rzecz, że oni rozmawiają ciągle i coś tam dalej. Ja chciałam... W pokoju tak jest. W kuchni jest to samo. Jak tam jest tłoczno, to trzeba uciekać. Żeby się zwolniła kuchnia. Ale... Ale potem jak dalej wszyscy się kłębią w kuchni, no to rzeczywiście ja tam... Jak się rozgadają i coś tam dalej, no to nie da się wejść. Badacz: Przesiadują tam po prostu.

Magda: Dokładnie. I mnie to trochę denerwuje.
Z wypowiedzi tej trudno się zorientować, na czym konkretnie polega dyskomfort pojawiający się na tle stosunków społecznych. Magda maluje raczej bardzo pesymistyczny, wręcz wrogi obraz społeczności, do której nie należy i która jawi się jej jako zagrażająca. Za każdym razem, gdy badaczka pyta o przebieg zatrudnienia, Magda weksluje rozmowę na tory trudności w komunikacji między nią a kolegami z pracy. Bardzo symptomatyczna jest następująca wypowiedź:

Badacz: Ile godzin dziennie pracujesz?

Magda: Dwadzieścia cztery godziny na dobę

Mama: [śmiech] Chyba teraz przesadziłaś troszkę.

Magda: Około ośmiu godzin albo i nawet dłużej.

Mama śmieje się z czegoś, co w głębokim sensie wcale nie jest śmieszne. Wypowiedź Magdy można zrozumieć $\mathrm{w}$ kontekście psychoanalitycznym jako wyraz bezgranicznego znużenia, zniechęcenia i awersji do pracy. Mówiąc o konieczności jeżdżenia do pracy samochodem razem $\mathrm{z}$ tatą, kilkakrotnie używa słów: „niestety; ubolewam nad tym”. Kolejny wątek to pytanie, $\mathrm{w}$ jaki sposób praca wpłynęła na życie Magdy:

Badacz: Czy ta praca jakoś zmieniła twoje życie? Mama: To zmieniło na lepsze.

Magda: Nie zmieniło, tylko rozwaliło. Ja nie jestem w pracy, tylko w domu. Codziennie.

\section{Badacz: Odwrotnie.}

Magda: Odwrotnie.

Tę wypowiedź również można traktować jako „freudowską" pomyłkę, wskazującą na udręczenie praca. Mama ma na ten temat diametralnie odmienne 
zdanie. Można odnieść nieodparte wrażenie, że mama ma swoją teorię na temat roli pracy w życiu jej córki i zupełnie nie słucha, co na ten temat ma do powiedzenia Magda.

Badaczka podjęła jeszcze jedną kwestię: czy w przyszłości Magda widzi dla siebie jakąś pracę oprócz znienawidzonej pracy biurowej. Magda zaczyna mówić tak cicho, że trudno ją zrozumieć:

Najbardziej to chciałabym... najbardziej to mnie interesuje... w kwiaciarstwie. I takie kwiaty się zajmować. [...]W szkole mieliśmy zajęcia z panią psycholog, z panią pedagog szkolną i też z taką panią od bukieciarstwa. No i tam robiliśmy właśnie różne kwiatki. Robiliśmy taki bukiet ślubnych kwiatów. No i... przyniosłam do domu, a potem to mama wyrzuciła.

Można to metaforycznie skomentować, że nawet miłe wspomnienia Magdy zaprawione są "łyżką dziegciu".

[...] Zaczęłabym karierę taneczną. Kocham tańczyć, sprawia mi to wielką przyjemność. Poznać sławnych ludzi. [...] Sama uczę się układów, włączam muzykę, która [cisza] gra mi w sercu, w całym ciele mi płonie. Muzyka jest zawsze w duszy, którą gra. [...] Albo tak się bawię w "Szansę na sukces", wymyślam osoby, które są koło mnie i tam śpiewam, no i wygrywam.

Magda żyje w dwóch różnych światach: w świecie upiornej rzeczywistości, $\mathrm{w}$ którym ciągle zmuszana jest do znienawidzonej pracy, oraz w świecie marzeń i fantazji, który jest ucieczką od prozy życia. Rodzice widzą jej życie w zupełnie innym świetle, uważają, że wiele zyskuje przebywając w towarzy- stwie osób „pełnosprawnych”, taki też realizują plan związany z karierą zawodową ich córki. Magda jest całkowicie podporządkowana rodzicom. W czasie wywiadu z nią obecna była matka, następnie matka była też obecna podczas rozmowy z ojcem. $Z$ kolei Magda oraz ojciec byli obecni podczas wywiadu z matką. Cała rodzina jest skoncentrowana wokó Magdy. Matka mówiąc o różnych wydarzeniach z jej życia, używa liczby mnogiej, przykładowo: „myśmy nie miały tyle zaparcia i siły, żeby się uczyć; w pracy ja to nazywam cofaniem, bo w szkole musiałyśmy bardziej umysł ćwiczyć". Matka w specyficzny sposób traktuje pracę zawodową Magdy. Z jednej strony z jej wypowiedzi można wywnioskować, że praca Magdy jest "na niby”, tylko po to, by zająć jej czas, by nie siedziała w domu i się nie nudziła. Jednak z drugiej strony to "na niby” jest traktowane niezwykle serio jako konieczność spędzania ośmiu godzin dziennie w pracy mimo świadomości, że to dla Magdy zdecydowanie za długo.

Magda zaczęła pracę 8 godzin dziennie przez pięć $d n$ w tygodniu. Ale to jakby nie do końca się sprawdzito i ze względu na to, że była zmęczona, a po drugie jakby otoczenie wymogło, że musieliśmy ograniczyć tę Magdy pracę. Chodzi 3 bądź 4 razy w tygodniu na 8 godzin. Jest to nasza wygoda, ponieważ jeździ $\mathrm{z}$ tatą $\mathrm{i}$ wraca $\mathrm{z}$ tatą. Magda nie jest samodzielna, nie porusza się po mieście sama. W związku z tym ja już nie muszę główkować, jak to zrobić, gdzie się zwolnić, żeby po nią pojechać albo załatwić kogoś, żeby ją przywiózł czy zawiózł.

Ten fragment wywiadu nie jest do końca zrozumiały: matka twierdzi, że 8-godzinny dzień pracy Magdy spowodowany jest wygodą dowozu, ale jeśli jest to jedyny powód, to wydaje się dziwne, dlaczego Magda jest zmuszana do wielogodzinnego pobytu w miejscu pracy, zamiast po prostu wynająć taksówkę i nie jeździć za każdym razem z tatą.

Matka tłumaczy także, w jaki sposób „otoczenie wymogło" ograniczenia liczby dni tygodniowo spędzanych przez Magdę w pracy:

Konflikt był wtedy, kiedy Magda chodziła na 8 godzin przez 5 dni w tygodniu. Wyszło, że „A, to córeczka tatusia, pana dyrektora, zatrudniona i jej wszystko wolno". Jakby brak zrozumienia osób zupełnie [cisza]. Nie wiedzieli, że to jest dla niej, że nie chodzi ona tam, żeby zarabiać, ale dlatego, żeby nie siedzieć w domu i mieć to towarzystwo i wyjść między ludzi. Zupełnie inaczej to środowisko odebrało. A ponieważ ona ma te swoje przypadłości, takie jak, że sama ze sobą rozmawia, często to robi głośno, to... jeśli ktoś ma się nad czymś skupić, a tutaj bez przerwy słyszy rozmowy między Magdą a osobą wymyśloną, to jest to męczące. W związku z tym ograniczenie do 3 dni, aby ci ludzie mieli szansę odpoczynku od Magdy, bo taki pomysł, żeby siedziała sama w odrębnym pokoju to bez sensu, bo nie o to chodziło. [...] Ci ludzie musieli, muszą się jakoś przemęczyć. Żeby im dać też szansę psychicznego odpoczynku, to ona chodzi 3 dni w tygodniu. No najlepsze wyjście byłoby wtedy, gdyby ona mogła pracować 4 godziny, bo jej koncentracja też by była lepsza. No ale mówię, to jest moja wygoda po prostu.

Matka Magdy, razem z mężem, zaprojektowali dla córki „,nowy wspaniały świat”, w którym ich dziecko mogłoby bezkolizyjnie funkcjonować, gdyby tylko inni ludzie wykazali odrobinę dobrej woli i zrozumienia. Aby zapewnić sobie ich przychylnośc, Magda podejmuje działania „naprawcze”:

Czasami po prostu człowiek przychodzi z pracy zmęczony, zły na kogoś, niezadowolony, ale myślę, że ona tam towarzysko w jakimś sensie... no chyba jest zadowolona. Ona od podstawówki chodziła do integracji. Wszędzie chce się wkupić. Ona się tego nauczyła, że jest inna i żeby zaskarbić sobie przychylność ludzi, stara się, jak może. Ona to słodyczami, ciastem, tego typu rzeczy [śmiech] stara się osoby przekupić. Chyba w pracy też, bo to ciasto co jakiś czas musi do pracy zanieść. A propos tego podpuszczania, to jak ktoś jej mówi, „,A przyniosłabyś ciasto”, to oczywiście Magda od razu jest gotowa i to ciasto musi zrobić i przynosi. Czy tam, nie wiem, „A kawę może byś dobrą przyniosła", więc oczywiście Magda musi to spełnić i od razu musi zakupić puszkę kawy.

Wydaje się, że matka nie traktuje poważnie życiowych dramatów córki, uważając je raczej za śmieszne anegdotki. „Wkupywanie się w łaski” - określenie, którego użyła matka - to nie uwłaczający ludzkiej godności manipulatorski proceder, ale „legalny" sposób na zaskarbianie sobie czyjejś przychylności.

Na pytanie badaczki, czy matka widzi możliwości pracy Magdy w przyszłości, matka udziela wymijających odpowiedzi, po dłuższej wymianie zdań stwierdza w końcu:

Magda szybko się dekoncentruje, szybko się jakby.. nie nudzi, ale wpada w ten swój świat i zaczyna sobie wymyślać różne historie. Zupełnie wtedy w tych swoich historiach potrafi się zagubić, w tym świecie 
nierealnym. Wydaje mi się, że w pracy będzie musiała mieć kogoś, kto ją sprowadzi, ściągnie z powrotem do tego, co ma robić. [...] Na otwartym rynku na pewno nie da sobie rady. W dzisiejszych czasach i w takich relacjach międzyludzkich nie da sobie rady.

Ojciec Magdy kompletnie nie zdaje sobie spray z dylematów egzystencjalnych, na które nieustannie narażona jest jego córka. Nie przyjmuje do wiadomości tego, że w pracy nie czuje się ona na swoim miejscu i zupełnie nie bierze pod uwage jej cierpienia. Jest technokratą ubierającym przeżycia Magdy w racjonalnie skonstruowaną siatkę procesów „zarządzania zmianą":

Nie wiem, czy zna pani taki wykres zarządzania zmianą? Jeżeli chcę mieć podział wydajności i musimy zaimplementować zmiany, to jest najpierw okres buntu, jest spadek wydajności. Ten okres buntu dzieli się jeszcze na parę, ale jest generalnie taki protest: jestem przeciwny, nie, nie uda się, jest źle, po co ta zmiana? I tak dalej. Jak ona trwa, to potem się wypłaszcza, tak na bardzo niskim poziomie, to taki proces poddania się. Czyli trudno, jest jak jest, już nic nie zmienimy. Potem zaczyna się już pomału taka krzywa wznosząca. To jest taki okres akceptacji na zasadzie „No dobra, może spróbujmy, może nie będzie aż tak źle". No i potem jest okres przekonania, czyli „Kurczę, i tak można”. I powrót do tej wydajności. No to jest taki elementarny, podręcznikowy proces zarządzania zmianą. I myśmy go dokładnie przeszli. Tak, czyli najpierw okres buntu, czyli dyrektor zatrudnił córeczkę. Córeczka zabiera nam miejsca pracy. Córeczka trzasnęła drzwiami, więc w związku z tym jest agresywna. Córeczka na pewno kabluje tatusiowi. No cały taki model na nie, my tego nie chcemy i tak dalej.
To się pogłębiło i szerokim hukiem rozeszło. Ileś tam spotkań, łącznie z dyrektorem generalnym. Niestety, było również tak, że osoby, które najbardziej dezorganizowały pracę, musiały ją opuścić. Dzisiaj jesteśmy z powrotem na tym poziomie już pełnej wydajności, pełnej akceptacji, zrozumienia, aprobaty. Więc dzisiaj to się zdecydowanie wyprostowało i raczej ten konflikt taki duży to już jest historia. Ale naprawdę to jest podręcznikowe przejście zmiany, tak. Aczkolwiek kosztuje to ileś tam nerwów, zdrowia i myślę, że wszystkich, nie tylko Magdę, mnie, ale też tamtych osób, które się z tym stykają.

Ojciec, jak się wydaje, stracił kontakt ze światem Magdy i ze światem międzyludzkich stosunków, w którym ona przebywa. Rzeczywistość, z którą nie stracił kontaktu, to racjonalne procesy biurokratycznych urojeń. On także, podobnie jak Magda, radzi sobie ze społecznym światem metodą przekupstwa:

Wywalczyliśmy 3/5 etatu, więc w związku z tym ktoś to musi uzupełnić. Te osoby wsparciowe to jedna z nich uzupełnia te 2 dni, w których Magdy nie ma. On to robi po godzinach pracy, na umowę zlecenie, z takim samym wynagrodzeniem jak Magda. Między innymi to też zmieniło spojrzenie na Magdę, bo to jest dla kogoś dodatkowe źródło zarobków. Też jest w cudzysłowiu pewna wdzięczność za umożliwienie kolejnych pieniędzy.

Ojciec, podobnie jak matka, sądzi, że praca bardzo pozytywnie wpłynęła na życie Magdy:

Malowanie się czy strojenie się, to naprawdę sprawia przyjemność, że ona w pracy musi wyglądać. Druga rzecz, to że ona naśladuje. To też naśladuje również te pozytywne wzorce, tak. To znaczy funkcjonuje normalnie, że tak powiem, osób dorosłych. [...] Ona ma wzorce po prostu takiego normalnego funkcjonowania jakby w normalnym życiu. I ona też normalnie funkcjonuje.

Wbrew temu, co sądzi ojciec, sytuacja Magdy w miejscu pracy jest bardzo niestabilna. Matka mówi, że coraz częściej zdarza się, że Magda źle się czuje i nie chce iść do pracy. Wobec braku konieczności zarabiania pieniędzy jest to sankcjonowane, a dodatkowo przyczynia się do podniesienia komfortu życia zarówno Magdy, jak jej rodziców, a zwłaszcza współpracowników. Wydaje się, że ten sztucznie wykreowany, „ręcznie sterowany” wycinek rzeczywistości umrze w niedługim czasie śmiercią naturalną. Można tę sytuację potraktować jako eksperyment społeczny. Eksperymenty, jakie w latach pięćdziesiątych i sześćdziesiątych XX wieku przeprowadzali Millgram czy Asch, są obecnie zakazane ze względu na ich wattpliwy status etyczny, niemniej jednak do dzisiejszego dnia są one opisywane $\mathrm{w}$ podręcznikach psychologii społecznej jako pouczające przykłady funkcjonowania pewnych mechanizmów życia społecznego. Przypadek Magdy można porównać do jednego z bardziej drastycznych eksperymentów tego typu. Jest bardzo pouczający, daje wiele do myślenia. Ale jakie będzie miał skutki dla samej Magdy? Lepiej tego nie wiedzieć.

\section{Deklarowana chęć pracowania wśród osób pracujących}

Spośród dziewiętnastu osób badanych ponad połowa, czyli dziesięć osób, pracuje i dalej chce pozostać $\mathrm{w}$ zatrudnieniu. Mimo więc istnienia negatywnych przykładów omówionych powyżej, jest także wiele przykładów pozytywnych, ukazujących, jak wielką wartość może mieć praca w życiu upośledzonego umysłowo człowieka. Dla większości osób z tej grupy obecna praca nie jest ich pierwszą, bowiem zdobyli już bogate doświadczenie $\mathrm{w}$ dziedzinie zatrudnienia. Do wyjątków należy pan Grzegorz, który od pięciu lat pracuje w tym samym miejscu. Od niego samego trudno wydobyć, na czym polega jego praca, gdyż komunikacja werbalna jest mocno utrudniona. Pan Grzegorz mówi monosylabami, bardzo niewyraźnie, często wypowiada kwestie niezwiązane z tematem wywiadu. Powtarza, że lubi pracę, że jest fajnie: „Lubię, lubię pracę” (5a). Niemniej jednak kierownik WTZ ocenia jego kompetencje pracownicze bardzo wysoko:

Na pierwszy rzut oka... możliwościach niezbyt dużych, on świetnie funkcjonuje. Jest to jedna z najlepiej funkcjonujących osób niepełnosprawnych, jakąznam. Wie czego chce, ma swoje oczekiwania, ma swoje potrzeby. On nie potrafi ich... Inaczej: my nie potrafimy, ja nie potrafię ich... On werbalizację ma słabą i ja nie do końca potrafię zrozumieć. Natomiast życzyłbym takiej swobody w funkcjonowaniu też i niektórym pełnosprawnym. [...] Dyrekcja jest zachwycona, gros pracowników jest zachwyconych postawą. Przy takich werbalnych trudnościach to szalenie przyjemny, uprzejmy, sympatyczny, życzliwy człowiek. I znający realia funkcjonowania społecznego. On się ani nie narzuca, ani zbytnio nie wycofuje, bliżej mu do wycofania. Natomiast on się nie narzuca, co jest kłopotliwe w przypadku wielu osób niepełnosprawnych, którzy są nauczeni tego, że mogą z buciorami włazić, rzucać się na szyję i całować. A on bardzo, bardzo dobre wyczucie ma. (5f) 
Można więc powiedzieć, że dobre funkcjonowanie Grzegorza nie wynika z tego, że jego upośledzenie jest korygowane, a on sam „unormalniany". Przeciwnie, pozostawiona mu duża swoboda $\mathrm{w}$ „byciu sobą" powoduje, że czuje on, że jest na swoim miejscu, nie musi niczego udawać, do niczego aspirować, jest po prostu wolnym człowiekiem. Jednak z drugiej strony ten idylliczny obraz malowany prze kierownika WTZ nieco koryguje siostra pana Grzegorza, twierdząc, że praca jej brata jest pracą „pod specjalnym nadzorem":

Chciałabym, żeby pani zrozumiała, że my jesteśmy troszkę pod kloszem. Bo Grzegorz pracuje dla tego stowarzyszenia. [...] Więc jakby idea jest taka pozytywna, że jest to stowarzyszenie i taka poprawność. Zastanawiam się, jak by to rzeczywiście wyglądało, gdyby na przykład Grzegorz poszedł do pracy w normalnej instytucji. Jak by to wyglądało $\mathrm{w}$ świecie, że tak powiem, normalnym? Pytanie, czy każdy ma aż tak pozytywne spojrzenie. Obawiam się, że niestety, jeszcze chyba nie. (5d)

Okazuje się, że pozytywne doświadczenia związane z zatrudnieniem pana Grzegorza nie przydarzają się „ot tak”. Iluzoryczne jest mniemanie, że zatrudnienie nastąpiło na otwartym rynku pracy, wypowiedzi siostry świadczą raczej o tym, że stowarzyszenie mające $\mathrm{w}$ działalności statutowej zajmowanie się osobami niepełnosprawnymi jako pracodawca zatrudnia osoby (albo raczej jedną osobę) niepełnosprawne. Jest to kolejna pułapka związana z zatrudnianiem osób niepełnosprawnych intelektualnie: ich zatrudnienie tylko teoretycznie odbywa się na otwartym rynku. W rzeczywistości pracodawcą jest stowarzyszenie lub fundacja, które zatrudnienie osoby niepełnosprawnej intelektualnie traktują jako misję, a nie jako działanie podyktowane opłacalnością ekonomiczną. Jest więc to rozwiązanie, które z ekonomicznego punktu widzenia nie ma szans na powodzenie. Oczywiście, pan Grzegorz jako osoba szczególnie dobrze funkcjonująca ma szansę na zatrudnienie $\mathrm{w}$ takich cieplarnianych warunkach. Trzeba jednak pamiętać o tym, że „przeciętna” osoba niepełnosprawna intelektualnie nie funkcjonuje dobrze $\mathrm{w}$ żadnym układzie społecznym zakładającym istnienie siatki zobowiązań i powinności.

W badanej próbie znajdują się trzy osoby, które na co dzień mieszkają ze swoimi siostrami, najprawdopodobniej po śmierci rodziców. Pan Grzegorz jest jedną z tych osób, pozostałe dwie to pani Ola i pan Krzysztof. Nie jest chyba zbiegiem okoliczności to, że wszystkie trzy z tych osób należą do najlepiej funkcjonujących pracowników. „Obiektywnie" we wszystkich trzech przypadkach istnieją poważne przeciwwskazania do podjęcia pracy - pan Grzegorz uległ w przeszłości poważnemu wypadkowi samochodowemu podczas wędrówki po mieście, a mimo to nie zaprzestał samodzielnego poruszania się; pani Ola, według słów siostry, „przez wiele lat była w domu, ponieważ jej choroba była taka, że ona nosiła pieluchy do 32. roku życia, mało gdziekolwiek wychodziła, nie było mowy o żadnej pracy" (16d), oprócz tego pani Ola jest osobą niedosłyszącą; pan Krzysztof ma ataki padaczki i podczas drogi do pracy kilkakrotnie, na skutek interwencji przypadkowych osób, został odwożony do szpitala, a mimo to samodzielnie podróżuje do pracy w gospodarstwie ogrodniczym poza Warszawą, z koniecznością dwóch przesiadek i innymi ogromnymi utrudnieniami komunikacyjnymi. Można wysnuć przypuszczenie, że opieka siostrzana jest mniej „inwazyjna" niż opieka rodzicielska. W wielu wywiadach często pojawiają się stwierdzenia, że rodzice nie chcą żadnej pracy dla swoich dzieci, są nadopiekuńczy i w drastyczny sposób hamują aktywność, a tym samym ambicje i motywacje do działania osób dorosłych nazywanych dziećmi. Tymczasem kierownik WTZ następująco wypowiada się o siostrze pana Grzegorza:

On miał wypadek, przechodził na czerwonym świetle. Większość, albo 99,9\% niepełnosprawnych po takim zdarzeniu dostanie zakaz poruszania się, a 100\% pełnosprawnych nie dostanie zakazu, bo rodzice wiedzą, że mogą sobie zakaz wydać, a i tak oni będą chodzić, jak będą chcieli. Tu mamy przykład osoby, mówię o siostrze, która szalenie logicznie myśli. Ona patrzy przez pryzmat szczęścia brata, a nie przez pryzmat swojego bezpieczeństwa i swojego myślenia o tym, co niepełnosprawny może, a czego nie może, w czym się wyrobi, a w czym się nie wyrobi. To życie weryfikuje, w czym on się wyrabia. Życzyłbym wszystkim rodzicom, rodzeństwu niepełnosprawnych takiego podejścia. [...] Wiele osób tutaj, które nie mają przyzwolenia rodziny na różnego rodzaju działania, jest o głowę lepsza od niego, w różnych umiejętnościach. Ale nie mogą spróbować tego, a on może, dzięki siostrze. (5f)

W pozostałych dwóch przy padkach rozmówcy również podkreślają, że siostry pani Oli i pana Krzysztofa stawiają na samodzielność tych osób, unikają wyręczania ich we wszystkim i nie przejawiają postaw lękowych związanych z samodzielnym poruszaniem się oraz podejmowaniem nowych wyzwań.
O znaczeniu samodzielnego stanowienia o sobie w rozwoju potencjału osób niepełnosprawnych intelektualnie świadczy również przypadek pana Bartka, który pochodzi z rodziny, która według słów terapeuty składa się z upośledzonych umysłowo członków:

Bartek pracuje od wielu lat. Ta praca jest dla niego ważna. W domu sytuacja wygląda tak, że mieszka z mamą i ze starszym bratem. $\mathrm{W}$ domu postrzegany jest jako głowa rodziny $\mathrm{w}$ takim sensie, że taką rolę pełni. Tam odwrócone są sytuacje dlatego właśnie, że pracuje, ciągle musi. Bartek jest niepełnosprawny intelektualnie w stopniu umiarkowanym, tam wszyscy mniej więcej tak funkcjonują. Przy tym rodzaju niepełnosprawności obydwaj są, i mama. No nie wiem, tata już nie żyje, ale myślę, że też był niepełnosprawny intelektualnie. [...] Bartek od wielu lat pracuje, to jest jakiś zakład pracy chronionej. To jest dla niego ważne, bo to jakoś nobilituje w tej hierarchii rodzinnej, ma taki status trochę jak ojciec. (18e)

Z wywiadów z Bartkiem i jego mamą niewiele się można dowiedzieć. Mówią monosylabami, komunikacja jest bardzo utrudniona. Bartek na pytanie, gdzie pracuje, odpowiada:

Zbiórka autobusy. Ja takie ochrona, ja takie autobusy. I tak budują nas. Takie wody robimy. Piki takie robimy. Stacyjki robimy. Klapy takie anylowe też. Jest taka masina. Wody cała masina. A ja tylko ciągnę te. Tylko... Wstaję do roboty o czwartej. Idzie się do roboty. Muszę iść do roboty. (18a)

Mama pana Bartka mówi: „Ja nie pracuję, on sam pracuje. On sam chodzi do roboty". Na pytanie, na 
czym polega praca syna, odpowiada: „A robi takie pudełka. Robią takie coś, ja nie wiem. [...] Nigdy go nie wożę, sam idzie do roboty i sam przychodzi. Jeszcze miałabym go wozić?" (18b). Pan Bartek nie styka się z nadopiekuńczością, jest traktowany jak dorosły i tak też funkcjonuje. Jego zarobki odgrywają ważną rolę w utrzymaniu całej rodziny.

Z niejako odwrotną sytuacją mamy do czynienia w przypadku pana Andrzeja. Jest to osoba komunikatywna, opowiada podczas wywiadu o przebiegu zatrudnienia i o licznych doświadczeniach z tym związanych. Kierownik WTZ, którego uczestnikiem przed sześciu laty był Andrzej, mówi o ogromnym wysiłku, jaki włożyli rodzice w edukację zawodową syna oraz w stwarzanie warunków umożliwiających mu podejmowanie różnych aktywności w dziedzinie zatrudnienia:

Był jednym z najsprawniejszych naszych uczestników. Potencjał jego był ogromny. Uznaliśmy więc, że tylko krótko będzie w WTZ i powinniśmy szukać dla niego różnych innych rozwiązań. Ale chyba najważniejsza w tym była postawa rodziców. Ma bardzo fajnych rodziców, którzy fajnie Andrzeja wychowali i zawsze mu mówili, że ta praca jest dla niego bardzo istotna. (15f)

Rodzice bardzo angażowali się $\mathrm{w}$ organizowanie warunków zatrudnienia. Znaleźli mu pierwszą pracę, następnie pomogli założyć działalność gospodarczą polegającą na wykonywaniu drobnych prac ogrodniczych oraz zdobyć na nią dofinansowanie z Powiatowego Urzędu Pracy:

Pilotowała mu wszystko matka, my pośredniczyliśmy tylko [...] dalej już wszystko matka załatwiała, zała- twiła dofinansowanie, kupiła ten sprzęt, zrobili sobie wykres, co oni będą robili. Czyli tak: wiosna - trawniki, jesień- liście, a zima - kupił sprzęt do odśnieżania. I taka miała być idea. Natomiast pojawił się mały problem, który chyba zawsze naszych uczestników dotknie, że jednak wszystko to pięknie, ale Andrzejowi potrzebne jest wsparcie, nie zrobi tego tak dokładnie, jak robią to firmy sprzątające profesjonalnie. Nawet jeśli jego ceny są atrakcyjne, to ktoś chce mieć zrobione dobrze, od kreski do kreski. [...] Robił to wśród jakichś swoich znajomych wokół i znowu pomagali mu matka i ojciec, czyli znowu zaangażowani rodzice. [...] Matka jest jego trenerem pracy, matka go wozi i on tę działalność cały czas prowadzi, ale... zaczęło być coraz mniej zleceń, nie ma się co oszukiwać i on znowu większość czasu zaczął spędzać w domu. (15f)

W czasie gdy przeprowadzany był wywiad, pan Andrzej pracował w dużej firmie ogrodniczej pod Warszawą. Wszyscy byli pełni dobrej woli: pan Andrze z determinacją powtarzał, że chce i musi pracować. Rodzice bardzo mocno wspierali go w tej decyzji. Pracodawca to „kapitalny facet, który daje szanse niepełnosprawnym” (15 f), a pracownik pełniący funkcję mentora twierdzi: „obaj z szefem żeśmy wymyślili jeśli chodzi o tę grupę niepełnosprawnych i okazuje się, że się sprawdziło, bo doświadczone osoby nie muszą się odrywać od skomplikowanych prac, a oni wykonują proste prace (15h)". A mimo to sytuacja w pracy wywoływała eskalację napięć i konfliktów, co ostatecznie spowodowało, że kilka miesięcy po przeprowadzeniu wywiadu Andrzej został zwolniony. Kierownik WTZ, znający sytuację pana Andrzeja od przeszło dziesięciu lat, upatruje przyczyny trudności $\mathrm{w}$ niskiej - wbrew deklaracjom samego Andrzeja - motywacji do pracy. An- drzej nie musi zarabiać pieniędzy, pracowanie nie jest dla niego życiową konicznością, a tylko ubarwieniem codziennego życia. Ponadto nie czuje się on osobą dorosłą, odpowiedzialną za własne życie:

Andrzej cały czas opiera się na rodzicach. Jeżeli $\mathrm{w}$ tym momencie rodzic by powiedział, że nie będzie woził Andrzeja, to de facto ta praca jest pod znakiem zapytania. Czyli nie udało się, tę samodzielność ma ograniczoną. I on cały czas jest pod kuratelą rodziców. Wszystkie te działania są kapitalne, ale gdzieś jest wszędzie rodzic. No bo system naszego państwa nie pozwala na to, żeby miał trenera pracy, bo nie ma tych pieniędzy, żeby go zatrudnić. (15f)

Sytuacja zawodowa Andrzeja była (jest?) niestabilna, ponieważ - podobnie jak to miało miejsce w przypadku pani Magdy - rodzice „ręcznie sterują" rzeczywistością, starając się ją dopasować do specyficznych potrzeb i wymagań ich dziecka. Rzeczywistość jednak stawia opór, Andrzej ciągle popada w konflikty z osobami, które nie chcą wkładać wysiłku w rozumienie jego specyfiki. W sumie więc, mimo ogromnego wysiłku rodziców i dużego zaangażowania w pracę Andrzeja, jego kariera zawodowa nie należy do udanych.

Dotychczas omówiona została sytuacja zawodowa sześciu osób spośród jedenastu pracujących. Pozostałe pięć osób to osoby czujące się komfortowo w pracy i zamierzające dalej kontynuować zatrudnienie. Spośród tych osób dwie pracują mniej niż rok. W przypadku pierwszej osoby praca ma walor zdecydowanie pozytywny: ,jak on tam poszedł, widać że jest uśmiechnięty, dobrze ubrany, zadbany, jestem zachwycona jego przemianą" (6g); druga osoba nie znajduje się w aż tak komfortowej sytuacji, ,jest zadowolony z tej pracy od tej strony, że ma tę pracę, że kontaktuje się z innymi osobami. Jest to coś nowego. Niestety, te relacje z kierowcą są tą częścią, która wpływa na niego negatywnie" (13e). Pozostałe trzy osoby mają doświadczenia długoletniego zatrudnienia, można więc powiedzieć, że praca zawodowa to stabilna okoliczność towarzysząca ich dorosłości.

Pan Leszek był starannie przygotowany do zatrudnienia. Praktyki, staże, wsparcie Centrum DZWO$\mathrm{NI}$,to było solidne czasowo przygotowanie miejsca pracy. Wszystko było zgrane, dograne, dające podstawę gruntu i poczucie bezpieczeństwa" (7b). Obecnie od 7 lat pan Leszek pracuje w tym samym miejscu, matka opowiada o przebiegu zatrudnienia:

Nie muszę go budzić, ja nie mam w tym żadnego udziału. Ma poczucie obowiązku i to mu pomaga. On się dobrze w tym czuje i jest uśmiechnięty. Ma swój porządek dnia. Jest cudownie, ja go nie zmuszam, żeby wyszedł $\mathrm{z}$ domu. Motywacja jest w nim. Może zdaje sobie sprawę z etapów w życiu, szkoła, praca, patrząc na nas, na siostrę. [...] Gdy ktoś nas zapyta o Leszka, to zawsze odpowiadam, to jest najbardziej ułożony człowiek w naszym życiu. (7b)

Leszek jest bardzo związany z rodzicami, w wywiadach uczestniczyła razem cała trójka, mimo sugestii badaczki, że wolałaby rozmawiać z każdym z osobna. Rodzice zdają sobie $z$ tego sprawę i starają się kontrolować swój wpływ na życie syna:

Wydoroślał, jest dorosłym człowiekiem radzącym sobie $\mathrm{w}$ życiu, ale nie $\mathrm{w}$ sensie podejmowania decyzji. To jest niedopracowane. Ta więź jest ogromna 
między nami, może należałoby nad tym popracować. Ma trudności z mówieniem i patrzy na mnie, gdy ja jestem. W pracy musiał sobie radzić, musieli się nauczyć jego, z nim porozumiewania. Szanuję tę sferę Leszka. Po to są opiekunowie, byśmy odpoczęli, żebyśmy na siłę się tam nie pakowali. Cieszę się, że radzi sobie poza naszą obecnością. $(7 \mathrm{~b})$

Sukces kariery zawodowej Leszka to wypracowana równowaga między profesjonalnym wsparciem ze strony trenerów pracy i współpracowników a pełnym równoczesnego zaangażowania i dystansu wsparciem życiowym rodziców. Kariera zawodowa Leszka nie jest idylliczna: nie ma przyjaciół, nie uczestniczy też w żadnej grupie rówieśniczej; zdarza się, że popada w konflikty ze współpracownikami. Niemniej jednak wiedzie bogate, satysfakcjonujące życie dorosłego człowieka.

Wieloletnim stażem pracy może się poszczycić pan Bogdan. Jest on osobą bardzo samodzielną. Wywiadu udzielały terapeutka oraz (jedna z dwóch w badanej próbie) asystentka osoby niepełnosprawnej. O rodzicach pana Bogdana nie wspomina żadna z tych osób ani on sam. Bogdan mówi o pracy w samych superlatywach - bardzo lubi pracę, jest $\mathrm{w}$ niej dużo fajnych rzeczy i nie ma nic negatywnego, lubi o niej rozmawiać. Gdy badaczka kończy wywiad, Bogdan mówi: „Ooo, już? Tak szybko?” Według terapeutki „Bogdan jest takim człowiekiem bardzo pozytywnie nastawionym do życia, do świata, do ludzi, do zadań. Bardzo chętnym takim, zaangażowanym, włączającym się" (9e). Praca bardzo dobrze wpływa na jego życie: ,Jest zadowolony, ma poczucie dużej identyfikacji, bardzo podkreśla, że dobrze się tam czuje, że bardzo, bardzo... Jakby zewnętrznie widać po nim symptomy dużej satysfakcji z tego, co robi" (9e). Asystentka osoby niepełnosprawnej opowiada o wsparciu, jakie otrzymywał i ciągle otrzymuje Bogdan ze strony doradcy zawodowego, asystentki, trenera pracy. Podkreśla również ogromną rolę zaangażowanych współpracowników, pełniących w miejscu pracy funkcję mentorów. Bogdan według rozmówczyni może stanowić wzór do naśladowania: jest odpowiedzialnym, dojrzałym dorosłym mężczyzną. Ważne jest także jego życie osobiste: ma dziewczynę i myśli o rozpoczęciu samodzielnego życia, niezależnego od rodziców. Niemniej jednak „troszeczkę potrzebuje tego wsparcia, choćby takiego monitoringu ze strony trenera pracy" (9i). Przypadek pana Bogdana to jeden z najbardziej pozytywnych przykładów kariery zawodowej wśród wszystkich analizowanych przypadków.

Kolejny pozytywny przykład to przypadek pani Basi, która pracuje od wielu lat, początkowo w Zakładzie Aktywizacji Zawodowej, nazwanym przez terapeutkę „śluzą", a obecnie w Zakładzie Pracy Chronionej. „Ja ją postrzegam jako osobę niezwykle wrażliwą, ale też troskliwą. Potrafi i lubi dbać o innych" (12e). Mimo wielu pozytywnych doświadczeń Basi związanych z zatrudnieniem, terapeutka widziałaby ją na takim stanowisku, jakiego jeszcze w Polsce nie oferuje się osobom niepełnosprawnym:

Moim zdaniem praca idealna dla pani Basi, na przestrzeni kilkudziesięciu, może kilkunastu najbliższych lat, w Polsce nie będzie możliwa. Ja uważam, że pani Basia bardzo mocno odnalazłaby się w czynnościach opiekuńczo-wspierających osób starszych bądź chorych, które nie zakładałyby czynności pielęgnacyjnych. A w tej chwili, jak robimy takie rozeznanie... nie udało nam się znaleźć miejsc, które byłyby w stanie rozdzielić te funkcje stricte pielęgnacyjne, opiekuńcze od funkcji emocjonalnych. [...] My realizujemy już od kilu lat taki projekt wolontariatu osób z niepełnosprawnością intelektualną wobec osób starszych. Sprawdza się rewelacyjnie, ponieważ osoby starsze, jeżeli nawet mają wsparcie ze strony ośrodków pomocy społecznej czy usługi opiekuńcze, to nikt opłacany z ośrodka pomocy społecznej nie daje takiego poziomu emocjonalności, prawdziwości relacji. Dzielę się swoim doświadczeniem. Więc ja jestem też do tego głęboko przekonana i są osoby, które naprawdę gdzieś mają niesamowite pokłady... [...] U nas bardzo wiele osób o stosunkowo najwyższym poziomie rozwoju wspiera osoby z głębszymi stopniami niepełnosprawności i też się rewelacyjnie sprawdzaja. Poziom ich cierpliwości, ale też takiej troski, takiego... Bardzo trudno to opisać słowami. Ale naprawdę jest wiele osób, które się w tym realizują. Same będąc osobami z niepełnosprawnością intelektualną, świadczą wsparcie dla osób z niepełnosprawnością intelektualną głębszego stopnia. Też to bardzo fajnie funkcjonuje. Ale jakbyśmy mieli kogokolwiek zatrudnić, to już jest przeszkoda, bo asystent środowiskowy w domu samopomocy musi mieć takie kompetencje, $t u, t u$, tu. Dlatego moim zdaniem to jest przyszłość. Ja nie mówię, że nie, ale w jakiejś tam perspektywie czasowej. (12e)

\section{Podsumowanie}

Wszystkie przywoływane przypadki dotyczą osób zatrudnionych $\mathrm{w}$ przeważającej mierze $\mathrm{w}$ charakterze robotnika niewykwalifikowanego oraz - spora- dycznie - w charakterze niższej rangi pracownika biurowego.

Każdy z przedstawionych dziewiętnastu przypadków jest inny. $W$ przeprowadzonym badaniu nie chodziło o wypracowanie uogólnień czy przedstawienie typowej drogi kariery zawodowej osób niepełnosprawnych intelektualnie. Chodziło raczej o przybliżenie specyfiki myślenia tych osób o pracy i o swojej roli jako pracownika. „Niepełnosprawność intelektualna" to tylko etykieta obejmująca wspólną nazwą najrozmaitsze sposoby funkcjonowania społecznego, emocjonalnego czy interakcyjnego. Jako „Zwykli" członkowie społeczeństwa wiemy bardzo mało o specyfice myślenia czy rodzaju ekspresji w wyrażaniu emocji tych osób, ponieważ bardzo rzadko zabierają one głos $w$ tej sprawie. Są to osoby „które często nie są w stanie samodzielnie wyartykułować swoich sądów i opinii na temat swojej codzienności. Nie tylko bowiem osoby te rzadko z własnej woli wypowiadają się o doświadczanych potrzebach, ale również bardzo rzadko są o te odczucia pytane" (Nosal, Zaręba 2016: 198). W niniejszym badaniu osoby upośledzone umysłowo mogły zabrać głos we własnym imieniu. Można było ze zdziwieniem stwierdzić, że mylne jest społeczne przekonanie, iż rodzice pełnią rolę ich adwokatów i zawsze najlepiej wiedza, co jest dla nich dobre.

Powszechnie przyjmuje się, że istnieją dwie podstawowe formy komunikacji interakcyjnej: komunikacja werbalna i niewerbalna. Jak twierdzi Jakub Niedbalski (2013: 111), na podstawie długoterminowej obserwacji uczestniczącej, ,nie oznacza to jednak, że taki podział w jakikolwiek sposób wyczerpuje problematykę komunikowania się niepełnosprawnych 
intelektualnie podopiecznych, na tym ogólnym gruncie bowiem istnieje bardzo wiele specyficznych i danych tej właśnie grupie osób sposobów konstruowania komunikatów werbalnych i niewerbalnych". Stwierdzenie to znalazło pełne potwierdzenie w prezentowanym materiale. Osoby upośledzone umysłowo w stopniu umiarkowanym bądź znacznym rzadko kiedy są zupełnie „nieme”. Trudności w komunikacji werbalnej, niekiedy bardzo poważne, kompensowane są przez inne formy komunikacji, niekiedy równie czytelne i jednoznaczne jak wypowiadane słowa: wyraz twarzy ukazujący zadowolenie, złość, zniecierpliwienie, znudzenie; spojrzenie uważne, roztargnione, wyrażające pewność siebie lub zalęknienie; gesty wyrażające spokój lub nerwowość, uległość lub agresywność, potulność lub poczucie własnej wartości. Te i inne formy komunikatów umożliwiają obopólne wchodzenie w interakcje i głębokie porozumienie partnerów rozmowy. Osoby upośledzone umysłowo są często mistrzami w tego typu komunikacji. Powiedzieć nawet można, że $\mathrm{w}$ analizowanych studiach przypadków najlepiej społecznie i emocjonalnie funkcjonujące osoby nie są wcale tymi, które „najładniej” się wysławiaja. I odwrotnie.

Bariery komunikacyjne między osobami niepełnosprawnymi a „zwykłymi” członkami społeczeństwa wynikają często z trudności w werbalizowaniu myśli, ale mogą także, jak to wynika z analizowanego materiału, być powodowane nieuważnością otoczenia, protekcjonalizmem, infantylizowaniem drugiej osoby. Niepełnosprawność intelektualna jawi się więc w większym stopniu, niż to się na ogół zakłada, jako konstrukt społeczny. Znamienne jest, że te osoby badane, które znajdują się pod opieką sióstr (a nie matek), stosunkowo dobrze funkcjonują jako pracownicy, choć typy ich niepełnosprawności są bardzo dolegliwe. Świadczy to o tym, że ważnym czynnikiem "upośledzającym" może być nadopiekuńczość matek. O hamującym ambicje zawodowe swych dorosłych dzieci wpływie matek mówili w kilku analizowanych przypadkach terapeuci.

Ważne spostrzeżenie wynikające z przeprowadzonych badań dotyczy stopnia autonomii i możliwości swobodnego wyboru dróg życiowych przez dorosłe osoby upośledzone umysłowo. $\mathrm{W}$ jednym $\mathrm{z}$ analizowanych przypadków dostrzec można dramatyczną rozbieżność między tym, co sądzi o swoim życiu i jakie ma preferencje osoba niepełnosprawna a tym, do czego zmuszają ją rodzice. Sytuacja taka wskazuje na to, jak trudnym wyzwaniem może okazać się droga do akceptacji upośledzenia dziecka. Zdarza się, że rodzice nie są w stanie „pogodzić się" ze specyfiką dziecka wynikającą z niepełnosprawności intelektualnej i „na siłę” starają się je „unormalnić” ignorując krzyk rozpaczy osoby, która nie czuje się „na swoim miejscu”. W kilku innych analizowanych przypadkach pogodzenie się rodziców z niepełnosprawnością dziecka wiąże się z umożliwieniem mu swobodnego „wyrażania siebie”, co sprawia, że mimo wielu ograniczeń i dysfunkcji, dorosłe dziecko czuje się swobodnie, a poziom jego umiejętności społecznych jest zadziwiająco wysoki.

Przedstawione i zanalizowane powyżej dziewiętnaście przypadków długotrwałej lub incydentalnej, zaplanowanej lub przypadkowej, satysfakcjonujące lub degradacyjnej kariery zawodowej osób niepełnosprawnych intelektualnie to pewne spektrum oczekiwań, ambicji i możliwości, które udało się wy- odrębnić. Niektóre z analizowanych przypadków są negatywne, a niekiedy wręcz napawają grozą. Inne stanowią budujący przykład „małego heroizmu” osób, które codziennym wysiłkiem budują swą tożsamość i niezależność. Na podstawie przedstawionego materiału trudno udzielić jednoznacznej odpowiedzi na pytanie, jaką wartość ma praca w życiu upośledzonego umysłowo człowieka. Zależy to od bardzo wielu czynników. Przedstawione wypowiedzi samych osób upośledzonych oraz osób z ich najbliższego otoczenia społecznego skłaniają jed-

\section{Bibliografia}

Angrosino Michael (2010) Badania etnograficzne i obserwacyjne. Przełożyła Maja Brzozowska-Brywczyńska. Warszawa: Wydawnictwo Naukowe PWN.

Chase Susan E. (2009) Wywiad narracyjny. Wielość perspektyw, podejść, głosów. Przełożył Filip Schmidt [w:] Norman K. Denzin, Yvonna S. Lincoln, red., Metody badań jakościowych. Tom 2. Warszawa: Wydawnictwo Naukowe PWN, s. 15-55.

Denzin Norman K (2006) Sociological Methods: A Sourcebook. Aldine Transaction.

Denzin Norman K., Lincoln Yvonna. S. (2009) Metody zbierania i analizowania materiatów empirycznych. Przełożył Filip Schmidt [w:] Norman K. Denzin, Yvonna S. Lincoln, red., Metody badań jakościowych. Tom 2. Warszawa: Wydawnictwo Naukowe PWN, s. $1-14$

Gąciarz Barbara, Rudnicki Seweryn, red., (2014) Polscy niepetnosprawni. Od kompleksowej diagnozy do nowego modelu polityki spotecznej. Kraków: Wydawnictwo AGH.

Giddens Anthony (2001) Nowe zasady metody socjologicznej. Pozytywna krytyka socjolooii interpretatywnych. Przełożyła Grażyna Woroniecka. Kraków: Zakład Wydawniczy NOMOS. nak do refleksji. Podejmowanie zatrudnienia przez osoby niepełnosprawne intelektualnie to „konieczność dziejowa". Nie sposób odwrócić biegu historii. A historia emancypacji osób niepełnosprawnych intelektualnie, która dokonuje się w ostatnich dekadach, to historia obejmująca ich prawo do ochrony zdrowia, do edukacji, do wyboru stylu życia, grupy rówieśniczej, sposobów spędzania czasu wolnego. Obecnie jako społeczeństwo jesteśmy świadkami rozszerzania się działań emancypacyjnych na sferę zatrudnienia. 
Nosal Przemysław, Zaręba Marta (2016) Niepetnosprawny (intelektualnie) jako osoba doświadczająca emocji [w:] Elżbieta Zakrzewska-Manterys, Jakub Niedbalski, red., Pasjonaci, kreatorzy, twórcy. Ludzie niepetnosprawni jako artyśsi, sportowcy, animatorzy mediów. Łódź: Wydawnictwo Uniwersytetu Łódzkiego, s. 197-229.

Ochman Karolina (2014) Dodatkowy chromosom 21 a starzenie sie - dla tych, którzy chca wiedzieć więcej [w:] Jolanta Wierzba, red., Zespót Downa i medycyna. Warszawa: Wydawnictwo „Bardziej Kochani", s. 130-159.

Ostrowska Antonina (2015) Niepetnosprawwi w społeczeństwie 1993-201. Warszawa: Wydawnictwo IFiS PAN

Silverman David (2008) Prowadzenie badań jakościowych. Przełożyła Joanna Ostrowska. Warszawa: Wydawnictwo Naukowe PWN.
Stake Robert E. (2009) Jakósciowe studium przypadku. Przełożyła Marta Sałkowska [w:] Norman K. Denzin, Yvonna S. Lincoln red., Metody badań jakościowych. Tom 1. Warszawa: Wydawnictwo Naukowe PWN, s. 623-654.

Struck-Peregończyk Monika (2017) Młode osoby niepetnosprawn jako beneficjenci działań z zakresu aktywizacji zawodowej [w:] Jakub Niedbalski, Mariola Racław, Dorota Żuchowska-Skiba, red Oblicza niepetnosprawności w teorii i praktyce. Łódź: Wydawnictwo Uniwersytetu Łódzkiego, s. 121-146.

Zakrzewska-Manterys Elżbieta (2017) Oblicza dorostości. Mieszkania treningowe dla osób z niepetnosprawnościa intelektualna [w:] Jakub Niedbalski, Mariola Racław, Dorota Żuchowska-Skiba, red., Oblicza niepetnosprawności w teorii i praktyce. Łódź: Wydawnictwo Uniwersytetu Łódzkiego, s. 197-232.

\footnotetext{
Cytowanie

Zakrzewska-Manterys Elżbieta (2018) Praca. Co to znaczy? Doświadczenia osób upośledzonych umystowo zwiazane z zatrudnieniem. „Przegląd Socjologii Jakościowej”, t. 14, nr 3, s. 126-156 [dostęp dzień, miesiąc, rok]. Dostępny w Internecie: ‘www.przegladsocjologiijakosciowej.org?. DOI: http://dx.doi.org/10.18778/1733-8069.14.3.08.
}

\section{Work. What Does It Mean? Employment-Related Experiences of Persons with Intellectual} Disability

Abstract: In the article, a question of what is the meaning of a paid job for grown-up persons with moderate or severe intellectual disability is discussed. On the basis of in-depth interviews, 19 case studies were analyzed, which describe experiences related to the employment of intellectually disabled Warsaw district inhabitants.

Keywords: intellectual disability, mental handicap, employment, adulthood, self-identity 